\title{
Contrasting, Species-Dependent Modulation of Copper-Mediated Neurotoxicity by the Alzheimer's Disease Amyloid Precursor Protein
}

\author{
Anthony R. White, ${ }^{1}$ Gerd Multhaup, ${ }^{2}$ Denise Galatis, ${ }^{1}$ William J. McKinstry, ${ }^{3}$ Michael W. Parker, ${ }^{3}$ \\ Rüdiger Pipkorn, ${ }^{4}$ Konrad Beyreuther, ${ }^{2}$ Colin L. Masters, ${ }^{1}$ and Roberto Cappai ${ }^{1}$ \\ 1 Department of Pathology, The University of Melbourne, Victoria 3010, and The Mental Health Research Institute, \\ Parkville, Victoria 3052, Australia, ${ }^{2}$ Center for Molecular Biology, The University of Heidelberg, Heidelberg D-69120, \\ Germany, ${ }^{3} T h e$ Biota Structural Biology Laboratory, St. Vincent's Institute of Medical Research, Fitzroy, Victoria 3065, \\ Australia, and ${ }^{4}$ German Cancer Research Center, Heidelberg D-69120, Germany
}

The amyloid precursor protein (APP) of Alzheimer's disease $(A D)$ has a copper binding domain (CuBD) located in the $\mathrm{N}$-terminal cysteine-rich region that can strongly bind copper(II) and reduce it to $\mathrm{Cu}(\mathrm{l})$ in vitro. The CuBD sequence is similar among the APP family paralogs [amyloid precursor-like proteins (APLP1 and APLP2)] and its orthologs (including Drosophila melanogaster, Xenopus laevis, and Caenorhabditis elegans), suggesting an overall conservation in its function or activity. The APP CuBD is involved in modulating $\mathrm{Cu}$ homeostasis and amyloid $\beta$ peptide production. In this paper, we demonstrate for the first time that Cu-metallated full-length APP ectodomain induces neuronal cell death in vitro. APP Cu neurotoxicity can be induced directly or potentiated through $\mathrm{Cu}(\mathrm{I})$-mediated oxidation of low-density lipoprotein, a finding that may have important implications for the role of lipoproteins and membrane cholesterol composition in AD. Cu toxicity induced by human APP, Xenopus APP, and APLP2 CuBDs is dependent on conservation of histidine residues at positions corresponding to
147 and 151 of human APP. Intriguingly, APP orthologs with different amino acid residues at these positions had dramatically altered $\mathrm{Cu}$ phenotypes. The corresponding C. elegans APL-1 CuBD, which has tyrosine and lysine residues at positions 147 and 151, respectively, strongly protected against Cu-mediated lipid peroxidation and neurotoxicity in vitro. Replacement of histidines 147 and 151 with tyrosine and lysine residues conferred this neuroprotective $\mathrm{Cu}$ phenotype to human APP, APLP2, and Xenopus APP CuBD peptides. Moreover, we show that the toxic and protective CuBD phenotypes are associated with differences in $\mathrm{Cu}$ binding and reduction. These studies identify a significant evolutionary change in the function of the CuBD in modulating $\mathrm{Cu}$ metabolism. Our findings also suggest that targeting of inhibitors to histidine residues at positions 147 and 151 of APP could significantly alter the oxidative potential of APP.

Key words: oxidative stress; neurodegeneration; transition metals; Caenorhabditis elegans; cell culture; lipoprotein
Alzheimer's disease (AD) is characterized by progressive neuronal dysfunction, reactive gliosis, and the formation of amyloid plaques in the brain. The major constituent of AD plaques is the amyloid $\beta$ peptide $(\mathrm{A} \beta)$ that is cleaved from the membranebound amyloid precursor protein (APP) (Glenner and Wong, 1984; Masters et al., 1985; Kang et al., 1987; Koh et al., 1990; Yankner et al., 1990; Hardy et al., 1998). The cause of the neuronal cell loss in AD is unclear but may be related to increased oxidative stress from excessive free radical generation (Martins et al., 1986; Smith et al., 1997; Bush, 2000; Sayre et al., $2000)$. One of the major potential sources of free radical production in the brain is from the transition metals, copper $(\mathrm{Cu})$ and iron (Fe) (Bush, 2000; Sayre et al., 2000). These metals are vital for normal cellular function because of their high redox activity. This redox potential has been successfully harnessed by a number of enzymatic pathways, including cellular respiration. However, if

Received June 13, 2001; revised Oct. 11, 2001; accepted Oct. 23, 2001.

This work was supported in part by grants from the National Health and Medical Research Council of Australia to C.L.M. and R.C. G.M. and K.B. were supported by the Deutsche Forschungsgemeinschaft and the Bundesministerium für Forschung und Technologie. We thank Dr. Robert Cherny and Irene Volitakis for assistance with ICP-MS analyses.

Correspondence should be addressed to Dr. Roberto Cappai, Department of Pathology, The University of Melbourne, Victoria 3010, Australia. E-mail: r.cappai@unimelb.edu.au.

Copyright (C) 2002 Society for Neuroscience $\quad 0270-6474 / 02 / 220365-12 \$ 15.00 / 0$ the redox reactivity of $\mathrm{Cu}$ and $\mathrm{Fe}$ is not strictly regulated, this can result in the generation of toxic reactive oxygen intermediates (ROIs) such as the hydroxy radical $(\bullet \mathrm{OH})$ (Smith et al., 1997). The potential for oxidative damage from ROI in the aging brain is further enhanced by the high oxygen consumption and relatively low antioxidant levels in brain tissue. To prevent transition metal-mediated oxidative stress, cells have evolved complex metal transport systems that deliver $\mathrm{Cu}$ and $\mathrm{Fe}$ to metalloenzymes and proteins. These include mammalian $\mathrm{Cu}$ chaperones that are involved in intracellular $\mathrm{Cu}$ trafficking to $\mathrm{Cu} / \mathrm{Zn}$ superoxide dismutase and the Wilson's disease $\mathrm{Cu}$ ATPase (Waggoner et al., 1999). The chaperones target the $\mathrm{Cu}$ atoms to specific intracellular proteins, which results in unbound $\mathrm{Cu}$ being essentially absent in the intracellular environment (Rae et al., 1999). Therefore, cuproproteins have an important role in maintaining cellular $\mathrm{Cu}$ metabolism (Andrews, 2001).

Both APP and $\mathrm{A} \beta$ can strongly bind $\mathrm{Cu}(\mathrm{II})$ and reduce it to $\mathrm{Cu}(\mathrm{I})$ in vitro (Hesse et al., 1994; Multhaup et al., 1996; Atwood et al., 1998; Cherny et al., 1999; Huang et al., 1999a,b). The APP $\mathrm{Cu}$ binding domain $(\mathrm{CuBD})$ is located in the $\mathrm{N}$-terminal cysteinerich region next to the growth factor-like domain (Hesse et al., 1994; Rossjohn et al., 1999). APP is a member of a multigene family that contains the paralog amyloid precursor-like proteins (APLP1 and APLP2). Orthologs have been identified in a diverse range of species, including Drosophila melanogaster, Xenopus lae- 
vis, Caenorhabditis elegans, puffer fish (Fugu rubripes and Tetraodon fluviatilis), and electric ray (Narke japonica) (Wasco et al., 1992; Daigle and Li, 1993; Slunt et al., 1994; Okado and Okamoto, 1995; Torroja et al., 1996; Iijima et al., 1998; Villard et al., 1998). The CuBD sequence is similar among the different APP family paralogs and orthologs, suggesting an overall conservation in its function or activity.

APP expression modulates $\mathrm{Cu}$ homeostasis because APP-/mice have elevated $\mathrm{Cu}$ levels in the liver and cerebral cortex when compared with APP $+/+$ mice (White et al., 1999b). In addition, elevated $\mathrm{Cu}$ concentrations reduce $\mathrm{A} \beta$ production and increase secretion of APP in a cell line transfected with human APP cDNA (Borchardt et al., 1999). This effect could be influenced by $\mathrm{Zn}$ or with $\mathrm{Zn}$ and $\mathrm{Cu}$ chelators (Borchardt et al., 2000). These studies provide strong evidence that APP has an important role in modulating cellular $\mathrm{Cu}$ metabolism in certain tissues, including the brain. Moreover, wild-type APP-expressing neurons $(\mathrm{APP}+/+)$ are significantly more sensitive to $\mathrm{Cu}$ toxicity than APP-deficient neurons (APP-/-) (White et al., 1999a), and interaction between APP $\mathrm{Cu}(\mathrm{I})$ species with hydrogen peroxide can result in $\mathrm{Cu}(\mathrm{I})$ oxidation to $\mathrm{Cu}(\mathrm{II})$ and APP fragmentation (Multhaup et al., 1998). Therefore, alterations to APP and/or $\mathrm{Cu}$ metabolism, as found in AD, could potentially result in increased APP $\mathrm{Cu}(\mathrm{I})$-mediated ROI generation and increased oxidative stress as well as altered APP processing to A $\beta$ (Lovell et al., 1998; Borchardt et al., 1999; Cherny et al., 1999; Sayre et al., 2000). However, full-length APP-mediated $\mathrm{Cu}$ neurotoxicity has not been directly demonstrated in vivo or in vitro.

In this paper, we used cell culture and cell-free lipid peroxidation assays to define the role of the APP CuBD in Cu toxicity. We demonstrate for the first time that $\mathrm{Cu}$-metallated human brainderived and recombinant full-length APP ectodomain oxidizes low-density lipoprotein (LDL) and induces neuronal cell death in vitro. Recombinant and synthetic proteins corresponding to the APP metal-binding ectodomains were used to demonstrate that APP $\mathrm{Cu}$ toxicity was specifically mediated by the $\mathrm{Cu}$-binding ectodomain between residues 135 and 166 of human APP. Toxicity was generated by this sequence in the presence of $\mathrm{Cu}$ but not other metals and involved reduction of $\mathrm{Cu}$ (II) by APP. Mutagenesis of the APP CuBD revealed that APP-mediated $\mathrm{Cu}$ toxicity was dependent on the central histidine residues H147, H149, and H151. The importance of the central histidine region in APP Cu toxicity was further supported by the fact that APLP2 and nonmammalian APP orthologs, which have a highly conserved central histidine region, could also potentiate $\mathrm{Cu}$-mediated toxicity. Importantly, APP orthologs with different amino acid residues at the histidine positions have dramatically altered phenotypes. The $C$. elegans APL-1 peptide (APL-1 $1_{\mathrm{CuBD}}$ ), which has tyrosine 147 and lysine 151 , strongly protected against $\mathrm{Cu}$ toxicity in vitro. Substitution of histidine residues 147 and 151 for tyrosine and lysine, respectively, in human and other toxic APP CuBDs conferred a protective phenotype to these peptides. These findings identify a significant evolutionary change in the function of the CuBD. The data also highlight the important role of the APP CuBD in both APP metabolism and neurotoxicity, possibly through a gain of function activity of APP resulting in perturbed $\mathrm{Cu}$ homeostasis.

\section{MATERIALS AND METHODS}

Materials. Poly-L-lysine, bathocuproine disulfonate (BC), bovine serum albumin (BSA), LDL, and trypsin were purchased from Sigma (St. Louis, MO). Metal salts were obtained from Ajax Chemicals or BDH Chemicals. Minimal Essential Medium (MEM) was obtained from Life Tech- nologies. Fetal calf serum (FCS) and horse serum (HS) were from the Commonwealth Serum Laboratories.

Recombinant APP18-611, APP18-146, APP124-189, APLP2, and APLP1. Recombinant secreted APP (APP18-611), APLP2, APLP1, APP18-146, and APP124-189 were produced in the methylotrophic yeast, Pichia pastoris. The expression of APP18-611, APLP2, and APLP1 has been described elsewhere (Henry et al., 1997, 1998; White et al., 1998). APP18-146 was generated by PCR using the primers CCC CGG GAT GCT GGA GGT ACC CAC TGA TGG and CCC CCG GGC TAA GTT TCG CAA ACA TCC ATC CTC. The PCR product was cloned as an XmaI fragment into the P. pastoris vector pHIL-S1 (Invitrogen, San Diego, CA). APP124-189 was generated by PCR using the primers GCT CGA GAA AA GAG AGG CTA GTG ATG CCC TTC TCG and GAA TTC TTA CAG TGG GCA ACA CAC AAA CTC. The PCR product was cloned as a XhoI-EcoRI fragment into the $P$. pastoris vector pIC9 (Invitrogen). The constructs were transformed into $P$. pastoris strain GS115 as described previously (Henry et al., 1997). Expressing clones were identified by silver stain SDS-PAGE analysis of the culture supernatants.

APP124-189 was purified to homogeneity in two steps. First, supernatant from a $P$. pastoris culture expressing the domain was concentrated, and buffer was exchanged into $20 \mathrm{~mm}$ TRIS buffer, $\mathrm{pH} 8.5$, containing 5 mM EDTA and applied to a QHyperD $1.6 \times 13 \mathrm{~cm}$ column (Biosepra) equilibrated in the same buffer. APP124-189, which eluted in the column flow-through, was concentrated and further purified on a Superdex 75 HR 10/30 gel filtration column (Amersham Biosciences) in $20 \mathrm{~mm}$ sodium phosphate buffer, $\mathrm{pH}$ 6.8, containing $1 \mathrm{~mm}$ EDTA. Pure APP124-189 eluted as a single peak. N-terminal amino acid sequencing and mass spectrometry confirmed the $\mathrm{N}$ terminus was intact, and the mass correlated with that of the predicted sequence. The protein was concentrated by ultra-filtration to a final concentration of $5 \mathrm{mg} / \mathrm{ml}$ in 20 mM phosphate buffer, $\mathrm{pH} 6.8$.

Purification of human brain-derived APP. Human brain-derived secreted APP was prepared as described previously (Moir et al., 1992). The proteins were concentrated, and buffer was exchanged into $20 \mathrm{~mm}$ HEPES, 138 mm NaCl, pH 7.4.

Chemical synthesis and purification of APP CuBD peptides. For solidphase synthesis of APP CuBD (see Tables 1-3), we used the Fmoc strategy (Merrifield, 1963; Carpino and Han, 1972) in a fully automated synthesizer (ABI 433). Peptide chain assembly was performed using in situ activation of amino acid building blocks by $2-(1 \mathrm{H}$-benzotriazole-1yl)-1,1,3,3-tetramethyluronium hexafluorophosphate. The purified material was analyzed by HPLC and laser desorption mass spectrometry (Vision 2000, Finnigan MAT). Purified peptides were dissolved in double-distilled water $\left(\mathrm{dH}_{2} \mathrm{O}\right)$ at a concentration of $700 \mu \mathrm{M}$ and stored at $-70^{\circ} \mathrm{C}$ until use.

Metallation of proteins and peptides. Brain purified APP, recombinant proteins, or synthetic peptides (500 $\mu$ l samples) were mixed with metalglycine solutions $[\mathrm{Cu}(\mathrm{II}), \mathrm{Fe}(\mathrm{II})$, or $\mathrm{Zn}(\mathrm{II})$ at a metal to glycine ratio of 1:6] at an equimolar or a two-fold metal to protein concentration unless stated otherwise. Metal-protein mixtures were incubated overnight at $37^{\circ} \mathrm{C}$ and then extensively dialyzed $\left[24 \mathrm{hr}\right.$ against two changes of $\mathrm{dH}_{2} \mathrm{O}$ (3 liters per change) at room temperature] using mini-dialysis cups with a $3500 \mathrm{kDa}$ cutoff (Pierce, Rockford, IL). Dialysis of proteins was also performed against PBS, pH 7.4, which resulted in metallated proteins with activity identical to $\mathrm{dH}_{2} \mathrm{O}$ dialysis.

Lipoprotein oxidation. Two different assays of metal-mediated lipid peroxidation were used. The first assay involved measuring the oxidative activity of metallated proteins. This was determined by mixing dialyzed metallated or native protein (at designated concentrations) with 0.5 $\mathrm{mg} / \mathrm{ml} \mathrm{LDL}$ for $24 \mathrm{hr}\left(37^{\circ} \mathrm{C}\right)$. Lipid peroxidation (LPO) was measured using a lipid peroxidation assay kit (LPO 486, Oxis International Inc., Portland, OR) as per kit instructions. The level of LPO was determined by comparing absorbance $(486 \mathrm{~nm})$ with LDL alone (100\% LPO). The second assay was used to measure the LPO activity of native proteins in the presence of free, nonprotein-bound $\mathrm{Cu}$. This involved adding nonmetallated peptides $(140 \mu \mathrm{M})$ to $0.5 \mathrm{mg} / \mathrm{ml}$ LDL together with $20 \mu \mathrm{M}$ $\mathrm{Cu}-\mathrm{Gly}$ and assaying for LPO as for the metallated proteins. The level of LPO was determined by comparing the absorbance $(486 \mathrm{~nm})$ with LDL + Cu-Gly (100\% LPO). As a negative control, LDL was also exposed to dialyzed $\mathrm{Cu}$-Gly solutions comparable with those used to $\mathrm{Cu}$ metallate the proteins.

Primary neuronal cultures. Cortical cultures were prepared as described previously (White et al., 1999a). Briefly, embryonic day 14 BL6Jx129sv wild-type or APP-/- mouse cortices were removed, dissected free of 
meninges, and dissociated in $0.025 \%(\mathrm{w} / \mathrm{v})$ trypsin. Dissociated cells were plated in 24-well culture plates (Greiner $\mathrm{GmbH})$ at a density of $2 \times$ $10^{6}$ cells $/ \mathrm{ml}$ in MEM with $10 \%$ (v/v) FCS and $10 \%$ (v/v) HS. Cultures were maintained at $37^{\circ} \mathrm{C}$ in $5 \% \mathrm{CO}_{2}$. This method produced cultures that were $95 \%$ pure for neurons (White et al., 1999a). Before experiments, the culture medium was replaced with MEM plus N2 supplements.

Cytotoxicity induced by the Cu-metallated APP. To determine the neurocytotoxic effects of the APP $\mathrm{CuBD}$, metallated and native proteins and peptides were added to 2-d-old primary neuronal cultures. Where indicated, cultures were also exposed to Cu-Gly (5 or $10 \mu \mathrm{M})$ or LDL. Positive control cultures were treated with Cu-Gly + LDL or the LPO product, 4-hydroxy-nonenol (HNE; Sigma Chemicals). Cultures were assayed for cell death using the lactate dehydrogenase (LDH) assay kit (Roche Molecular Biochemicals, Nunawading, Australia) as per kit instructions (White et al., 1999a).

$\mathrm{Cu}(\mathrm{I})$ detection in $\mathrm{Cu}$-metallated human-derived and recombinant proteins. $\mathrm{Cu}(\mathrm{I})$ generated by human brain-derived and recombinant proteins was measured using a modification of the $\mathrm{BC} \mathrm{Cu}(\mathrm{I})$ detection assay (Huang et al., 1999a,b). APP was metallated and dialyzed as described above. Metallated or native recombinant protein $(25 \mu \mathrm{M})$ or humanderived APP $(2 \mu \mathrm{M})$ was mixed with BC $(250 \mu \mathrm{M})$ in PBS, pH 7.4. Protein-BC mixtures were incubated at $37^{\circ} \mathrm{C}$ for $4 \mathrm{hr}$, and absorbance was measured with a Bio-Rad Model 550 plate reader. Absorbance readings for $\mathrm{BC}$ in $\mathrm{PBS}$ alone were subtracted from protein-BC readings to give $\mathrm{Cu}(\mathrm{I})$ levels as absorbance units per milliliter.

Real-time surface plasmon resonance analysis. Real-time binding experiments were performed on a BIACORE system equipped with the Upgrade kit (BIACORE). All experiments were performed at $37^{\circ} \mathrm{C}$. To prepare a metal chelating sensor surface, a nitrilotriacetic acid (NTA) immobilized sensor chip (sensor chip NTA, BIACORE) was exposed to copper solution $\left(100 \mu \mathrm{M} \mathrm{CuCl}{ }_{2}\right.$ in Milli-Q water) for $4 \mathrm{~min}$ at a flow rate of $5 \mu \mathrm{l} / \mathrm{min}$. For control experiments the sensor surface was treated as above, but EDTA $(1 \mu \mathrm{M})$ was injected for $4 \mathrm{~min}$.

Surface plasmon resonance analysis (SPR) buffers and solutions were filtered and degassed: eluent buffer (PBS, 0.005\% n-octylglycopyranoside, $1 \mu \mathrm{M}$ EDTA, pH 7.4), dispensor buffer (PBS, $0.005 \% n$-octylglycopyranoside, 3 mM EDTA), and regeneration solutions I (50 mm EDTA) and II (45 mM EDTA, $1 \mathrm{~mm} \mathrm{BC}$ ). After extensive washing to reset the surface with regeneration buffer I followed by eluent buffer, individual flow cells were loaded with copper solution to saturate the surface with $\mathrm{Cu}$ (II). The signal for binding of $\mathrm{Cu}(\mathrm{II})$ to NTA was 40 response units (RU) (see Fig. 4A). Peptide stock solutions were prepared in $1 \mu \mathrm{M}$ EDTA $(1 \mathrm{mg} / \mathrm{ml})$, diluted in PBS $(30 \mu \mathrm{g} / \mathrm{ml})$, and injected onto the surface for 2 min $(10 \mu \mathrm{l})$ by using the KINJECT command. The sensorgram was allowed to run for an additional $20 \mathrm{~min}$ after the end of injection to determine the dissociation kinetics. The following treatment with regeneration solution II for $6 \mathrm{~min}$ resulted in return to the baseline signal, indicating that the surface had been cleaned completely. Two observations are central to demonstrating the reliability of the present approach. First, peptides did not show binding to the NTA surface when it had not been loaded previously with $\mathrm{Cu}(\mathrm{II})$. Second, the injection of $1 \mathrm{~mm} \mathrm{BC}$ for 2 min onto the $\mathrm{Cu}(\mathrm{II})$-charged NTA surface did not affect surface-bound RU, showing that peptide binding was specific and exclusively mediated by $\mathrm{Cu}(\mathrm{II})$ but not $\mathrm{Cu}(\mathrm{I})$.

Sensorgrams were analyzed using the BIAevaluation 3.0 program (BIACORE), and kinetic constants were obtained by fitting curves to a single-site binding model ( $\mathrm{A}+\mathrm{B}=\mathrm{AB})$.

Statistical analysis. Data represent the mean and SE of at least three experiments performed in triplicate. ANOVA and Newman-Keuls tests were used to analyze data.

\section{RESULTS}

\section{Human brain-derived and recombinant APP $\mathrm{Cu}$ oxidize lipoproteins}

Although previous studies have shown that a peptide to the APP CuBD peptide (APP142-166) can induce $\mathrm{Cu}$-mediated neurotoxicity (White et al., 1999a), the ability of a physiologically relevant form of APP to be toxic in the presence of $\mathrm{Cu}$ is unknown. To examine this, we tested human brain-derived and recombinant APP for their ability to induce $\mathrm{Cu}$-mediated lipid peroxidation. Purified APP was first metallated by incubation with twofold molar excess of $\mathrm{Cu}$-Gly and then dialyzed extensively against distilled water to remove unbound $\mathrm{Cu}$. Human brain APP Cu (60
$\mathrm{nM})$ was incubated with LDL $(0.5 \mathrm{mg} / \mathrm{ml})$ for $24 \mathrm{hr}$, and LPO levels were measured. Soluble and membrane-associated APP Cu significantly elevated LPO levels (136 \pm 7 and $132 \pm 6 \%$, respectively) when compared with nonmetallated APP $(* * p<0.05)$ (Fig. 1A). Recombinant $\alpha$-secretase-cleaved APP695 ectodomain (APP18-611-Cu) (60 nM) also induced a significant increase $(214 \pm 20 \%)$ in LDL oxidation compared with either LDL alone or nonmetallated APP18-611 $\left({ }^{*} p<0.01\right)$ (Fig. $\left.1 A\right)$. Cumetallated recombinant APLP2 ectodomain (APLP2-Cu, $60 \mathrm{nM}$ ) induced elevated LPO levels $(168 \pm 21 \%)(* p<0.01)($ Fig. $1 A)$, but neither APLP1-Cu nor BSA-Cu (60 nM) had any effect on LPO, demonstrating that the LPO induced by APP18-611-Cu and APLP2-Cu is protein specific and not caused by a nonspecific protein-Cu-LDL interaction. Similarly, LPO was not induced by a dialyzed $\mathrm{Cu}-\mathrm{Gly}$ solution of the same concentration used to metallate APP, indicating that LPO is not caused by residual unbound $\mathrm{Cu}$ in the APP $\mathrm{Cu}$ solution.

To establish that the LDL oxidation by brain-derived APP involved reduction of $\mathrm{Cu}(\mathrm{II})$ to $\mathrm{Cu}(\mathrm{I})$, as described for recombinant APP (Multhaup et al., 1996), we measured $\mathrm{Cu}$ (I) generation by the $\mathrm{Cu}$-metallated brain APP using the bathocuproine assay. The absorbance of Cu-metallated brain APP was $0.080 \pm 0.009$ compared with $0.043 \pm 0.004$ for nonmetallated APP $(p<0.01)$ (data not shown), confirming that both recombinant and human brain-derived APP can generate bathocuproine-detectable $\mathrm{Cu}(\mathrm{I})$ (Multhaup et al., 1996). Importantly, these results demonstrate that although nonmetallated APP and APLP2 have no effect on $\mathrm{Cu}$-induced LDL oxidation, when loaded with $\mathrm{Cu}$ they potentiate high levels of LPO through generation of $\mathrm{Cu}(\mathrm{I})$.

\section{APP $\mathrm{Cu}$ induces neuronal cell death}

To determine whether the peroxidative activity of APP $\mathrm{Cu}$ can induce neurotoxicity, we exposed primary mouse cortical cultures to $\mathrm{Cu}$-metallated APP18-611. Cortical neurons were treated with APP18-611 (500 nM, nonmetallated), APP18-611-Cu (100-500 nM), or BSA-Cu (500 nM) (four exposures over $6 \mathrm{~d})$, and cell death was measured with the LDH assay. A dose-dependent increase in cell death was observed in cultures treated with 200 and 500 nм APP18-611-Cu $\left({ }^{*} p<0.05,{ }^{* *} p<0.01\right)$ (Fig. $\left.1 B\right)$ but not in cultures exposed to nonmetallated APP18-611 or BSA$\mathrm{Cu}$. These findings demonstrate for the first time that $\mathrm{Cu}$ metallated full-length APP (ectodomain) is toxic to neurons at physiologically relevant concentrations.

\section{Oxidation of LDL by APP Cu potentiates neuronal cell death in vitro}

Lipoprotein oxidation is a central feature of vascular illness and may have an important role in AD (Pitas et al., 1987; Schippling et al., 2000; Praticò et al., 2001). Our LDL oxidation experiments using Cu-metallated APP18-611 and brain-derived APP demonstrated a potent LPO potential for metallated APP. We therefore investigated the possibility that APP $\mathrm{Cu}$ could exacerbate neurotoxicity through oxidation of extracellular lipoproteins. Neuronal cultures treated with subtoxic APP18-611-Cu (100 nM) for $4 \mathrm{~d}$ (two exposures over $4 \mathrm{~d}$ ) in the presence of $100 \mu \mathrm{g} / \mathrm{ml} \mathrm{LDL}$ induced significant neuronal cell death $(52 \pm 3 \%)$ compared with LDL alone $(2 \pm 2 \%)(* * p<0.01)$ (Fig. 1C). APP18-611-Cu also induced significant cell death from lower concentrations of LDL ( $31 \pm 5$ and $15 \pm 2 \%$ from 50 and $25 \mu \mathrm{g} / \mathrm{ml}$ LDL, respectively), whereas cell death was not induced by either $100 \mathrm{~nm}$ nonmetallated APP18-611 or any concentration of LDL (data not shown). Coincubation of $100 \mathrm{~nm}$ APLP2-Cu with LDL resulted in $23 \pm$ 
$\mathbf{A}$ combinant and human brain-derived APP. LDL $(0.5 \mathrm{mg} / \mathrm{ml})$ was incubated with $60 \mathrm{nM} \mathrm{Cu}$-metallated or nonmetallated recombinant APP, APLP2, APLP1, or human brain-derived soluble $(\mathrm{Sol})$ or membrane-associated $(\mathrm{Mem})$ APP. Cumetallated APP and APLP2 induced significantly elevated LDL oxidation compared with untreated LDL or nonmetallated protein $\left({ }^{*} p<0.01,{ }^{* *} p<0.05\right)$. Cu-metallated APLP1 or BSA did not increase LDL oxidation. $B$, Neuronal cell death induced by APP $\mathrm{Cu}$. Primary cortical neurons were treated with APP18-611 (100-500 nM) or BSA-Cu (500 nM) ( 4 treatments over $6 \mathrm{~d}$ ). Cell death was determined with the LDH assay. APP18-611 and BSA-Cu had no effect on cell survival, whereas APP18-611-Cu induced a dose-dependent increase in neuronal death $\left({ }^{*} p<0.05,{ }^{*} p<0.01\right)$. $C$, Neuronal cell death induced by APP $\mathrm{Cu}$ and LDL. APP18611-Cu, APLP2-Cu, APLP1-Cu, or BSA-Cu (100 nM; 2 treatments over $4 \mathrm{~d})$ was incubated with $\mathrm{LDL}(100 \mu \mathrm{g} / \mathrm{ml})$. APP18-611-Cu and APLP2-Cu potentiated cell death from LDL exposure $(* * p<0.01)$. APLP1-Cu or BSA-Cu had no effect on LDL-mediated toxicity, and LDL alone had no effect on neurons. The LPO product HNE $(10 \mu \mathrm{g} / \mathrm{ml})$ or 5 $\mu \mathrm{M} \mathrm{Cu}+\mathrm{LDL}(25 \mu \mathrm{g} / \mathrm{ml})$ induced significant cell death $(* * p<0.01)$.
Figure 1. A, LDL oxidation induced by Cu-metallated re-

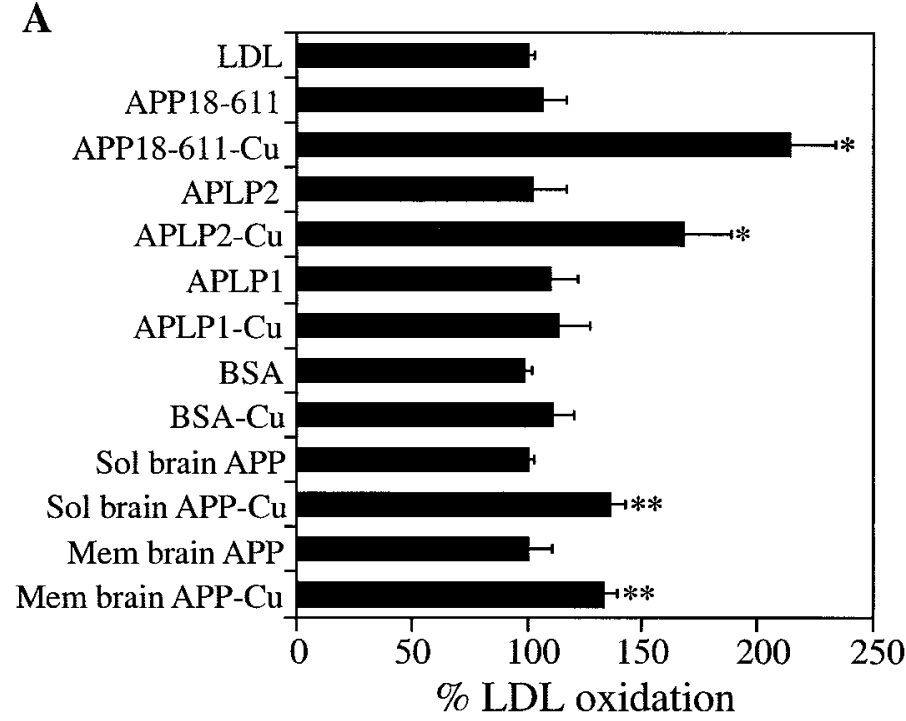

B

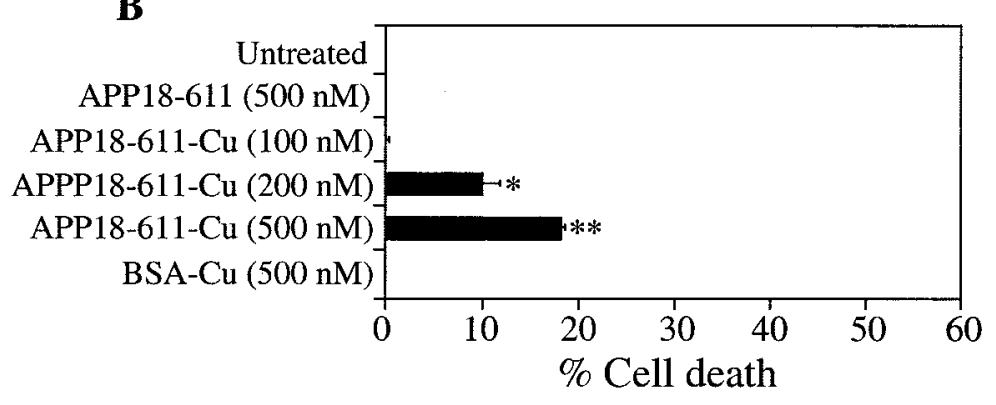

C

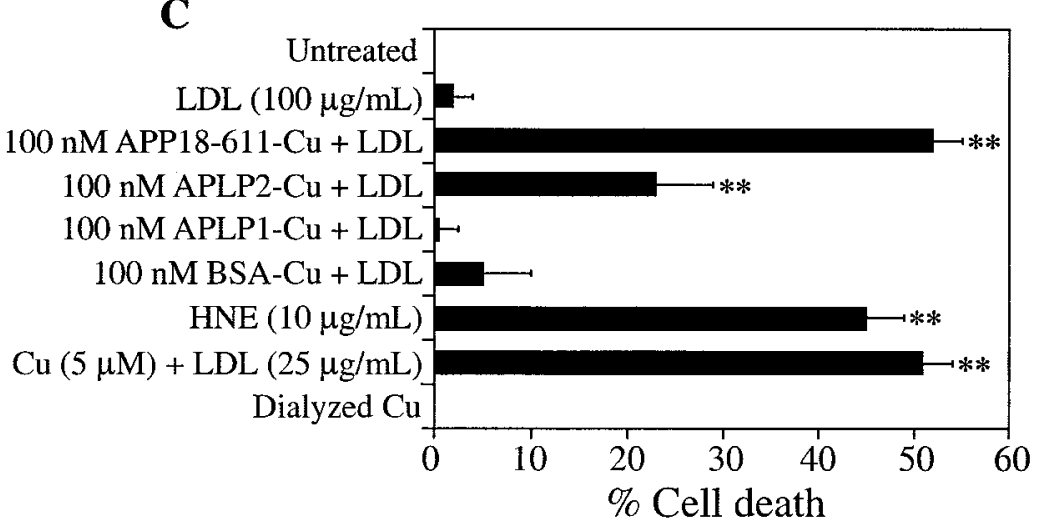

$6 \%$ cell death $(* * p<0.01)$ (Fig. $1 C)$. Importantly, cell death was not induced by APLP1-Cu, BSA-Cu, or a dialyzed $\mathrm{Cu}$ solution and LDL. The toxicity mediated by $100 \mathrm{~nm}$ APP18-611-Cu with $100 \mu \mathrm{g} / \mathrm{ml} \mathrm{LDL}$ was similar to the level induced by $10 \mu \mathrm{g} / \mathrm{ml}$ $\mathrm{HNE}$ or $5 \mu \mathrm{M} \mathrm{Cu}-\mathrm{Gly}+25 \mu \mathrm{g} / \mathrm{ml}$ LDL (Fig. $1 C$ ). These data clearly demonstrate that physiological levels of soluble APP and APLP2 have the potential to induce neuronal cell death through binding and reduction of $\mathrm{Cu}$.

\section{Localization of APP Cu-mediated toxicity to the APP metal-binding ectodomain}

To confirm that the CuBD of APP was responsible for APP18611 toxic activity, we assayed recombinant APP124-189, which encodes the APP CuBD. Inductively coupled plasma mass spec- trometry (ICP-MS) analysis showed that purified APP124-189 had very little metal bound, indicating that it was expressed in the apo form. APP124-189 was subsequently $\mathrm{Cu}$ metallated and applied to neurons for $4 \mathrm{~d}$. APP124-189-Cu directly induced elevated LDH release, whereas nonmetallated APP124-189, APP124-189-Zn, APP124-189-Fe, and APP18-146-Cu had no effect on cell survival ( ${ }^{*} p<0.0$ ) (Fig. $2 A$ ). Titration of APP124$189-\mathrm{Cu}$ revealed that metallated protein concentrations as low as $325 \mathrm{~nm}$ induced significant cell toxicity ( $\left.{ }^{*} p<0.01\right)$ (Fig. 2A). APP124-189-Cu could also potentiate neurotoxicity from exogenous LDL (data not shown). We also examined the ability of APP124-189 to induce LPO. Incubation of nonmetallated APP124-189 (0.3 $\mu \mathrm{M})$ with LDL did not alter LPO levels com- 
A

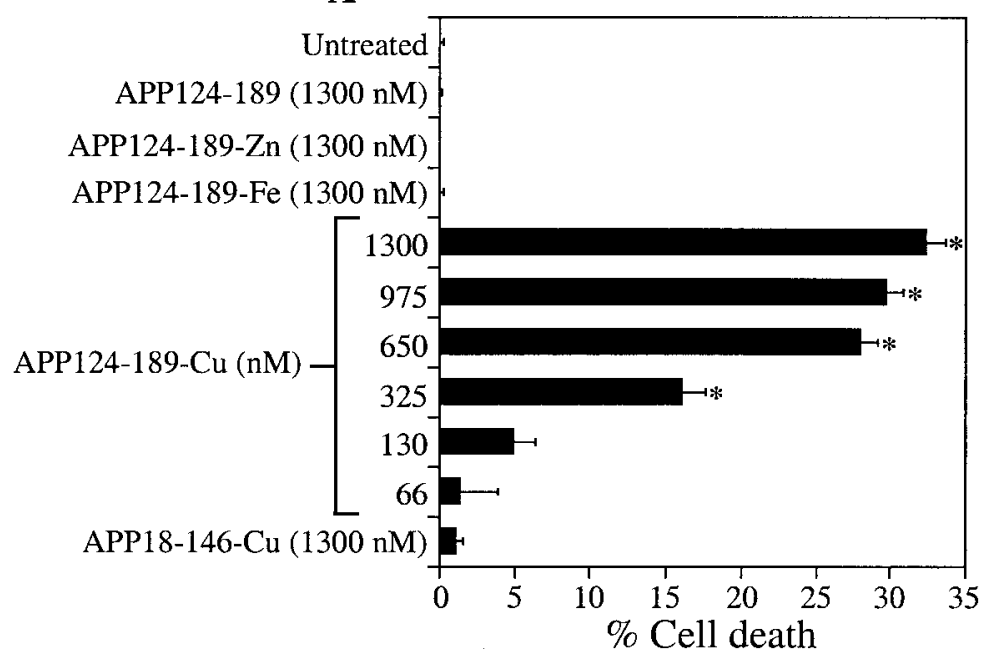

B

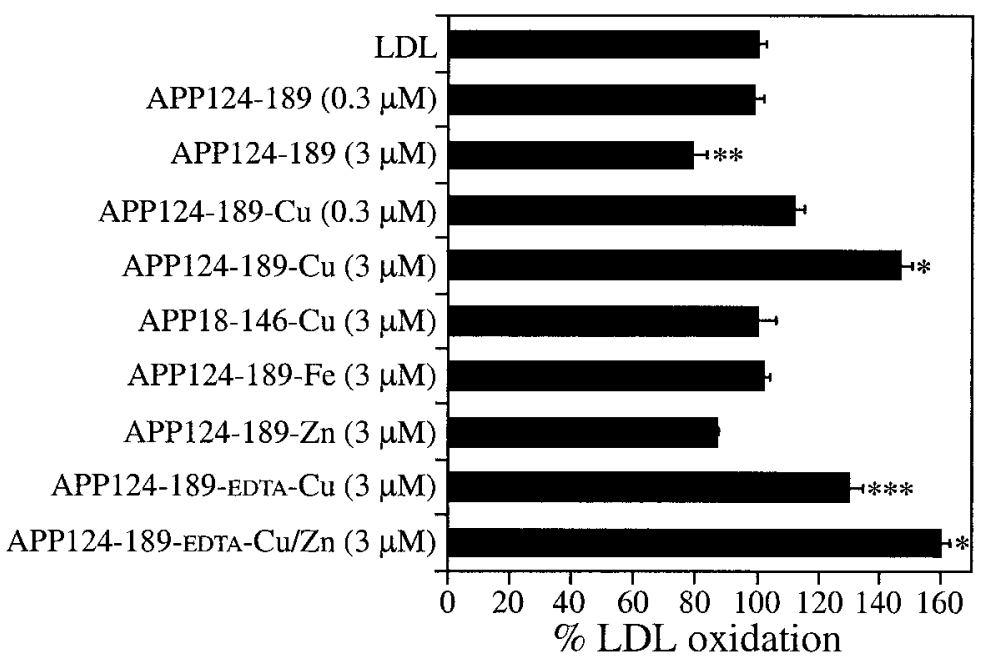

C

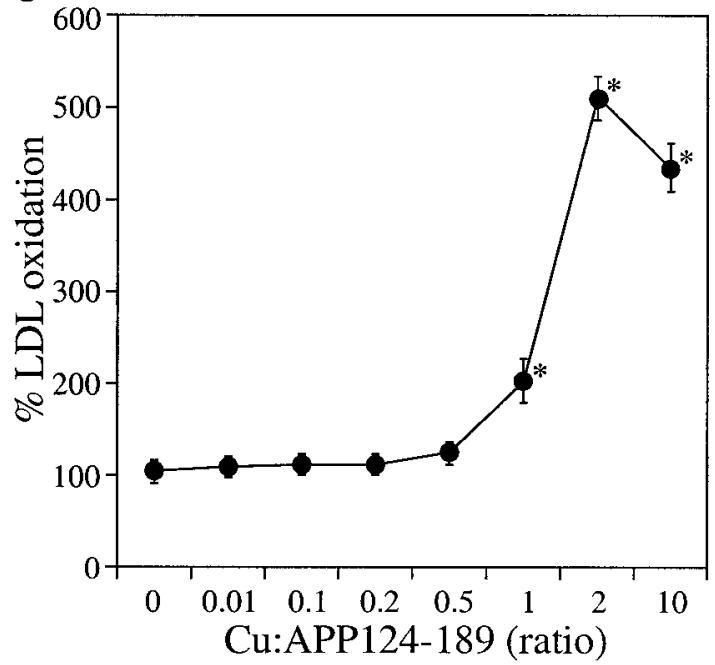

D

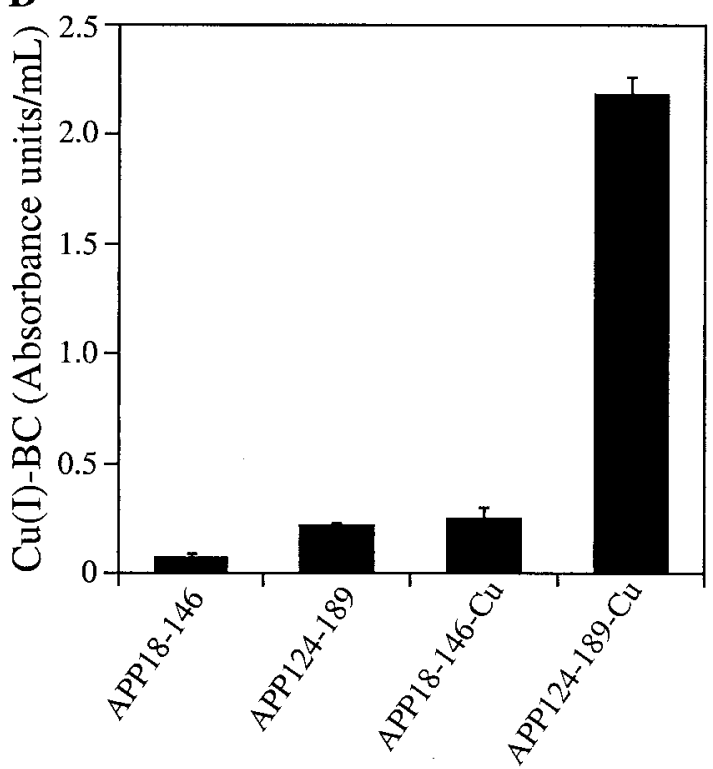

Figure 2. A, Cell death induced by Cu-metallated APP124-189. Primary cortical neurons were treated with APP124-189 after metallation with Cu, Fe, or Zn. Cell death was determined with the LDH assay. Nonmetallated APP124-189, APP124-189-Fe, and APP124-189-Zn (1300 nM) had no effect on neuronal cell death. APP124-189-Cu $(66-1300 \mathrm{~nm})$ induced a dose-dependent increase in neuronal cell death $\left({ }^{*} p<0.01\right)$. APP18-146-Cu did not increase neuronal cell death. $B$, LDL oxidation induced by $\mathrm{Cu}$-metallated human APP124-189. LDL $(0.5 \mathrm{mg} / \mathrm{ml})$ was incubated with 0.3 or $3 \mu \mathrm{M}$ metallated or nonmetallated APP124-189. Nonmetallated APP124-189 (3 $\mu \mathrm{M})$ induced a significant decrease in LDL oxidation compared with LDL alone $(* * p<0.05)$, whereas $3 \mu \mathrm{M} \mathrm{Cu}$-metallated APP124-189 significantly enhanced LDL oxidation at $3 \mu \mathrm{M}\left({ }^{*} p<0.01\right)$. APP124-189 metallated with $\mathrm{Fe}$ or $\mathrm{Zn}$ did not increase LDL oxidation. APP124-189 pretreated with EDTA induced significantly lower LDL oxidation after Cu metallation when compared with APP124-189-Cu (non-EDTA treated) $\left({ }^{* * *} p<0.05\right.$ compared with APP124-189-Cu). Metallation of EDTA-treated APP124-189 with $\mathrm{Zn}+\mathrm{Cu}$ resulted in LDL oxidation equivalent to APP124-189-Cu (non-EDTA treated). C, LDL oxidation induced by APP124-189 metallated with different concentrations of Cu-Gly. LDL was incubated with APP124-189-Cu after metallation with Cu-Gly at ratios of 0.01:10 (Cu/APP124-189). D, $\mathrm{Cu}(\mathrm{I})$ generation from APP124-189-Cu. Nonmetallated and Cu-metallated APP124-189 and APP18-146 $(25 \mu \mathrm{M})$ were incubated with $250 \mu \mathrm{M}$ BC, and $\mathrm{Cu}(\mathrm{I})$ generation $[\mathrm{Cu}(\mathrm{I})-\mathrm{BC}]$ was measured by spectrophotometry. The absorbance of $\mathrm{BC}$ alone was subtracted from each reading to give $\mathrm{Cu}(\mathrm{I})$ levels as absorbance units per milliliter. APP18-146, APP18-146-Cu, and APP124-189 induced negligible levels of Cu(I). APP124-189-Cu induced 10-fold higher $\mathrm{Cu}(\mathrm{I})$ levels than APP124-189 or APP18-146-Cu $\left({ }^{*} p<0.01\right)$.

pared with LDL alone. Interestingly, $3 \mu \mathrm{M}$ nonmetallated APP124-189 reduced LPO by $21 \%$ (Fig. $2 B)(* * p<0.05)$, suggesting that the recombinant apo-protein may be able to chelate residual metals from the LDL and inhibit endogenous LPO. After metallation, significant elevation of LPO was induced by $3 \mu \mathrm{M}$ APP124-189-Cu $(147 \pm 4.2 \%$ LPO compared with a dialyzed $\mathrm{Cu}$ solution; * $p<0.01$ ) (Fig. 2B), whereas APP124-189 loaded with $\mathrm{Zn}$ or Fe had no effect on LPO (Fig. $2 B$ ). In addition, the APP CuBD did not induce LPO after metallation with a large range of metals (data not shown). $\mathrm{Cu}$ metallation of the control protein APP18-146, which corresponds to the APP growth factor domain (Rossjohn et al., 1999), also failed to induce LPO because it lacks the CuBD.

The influence of the $\mathrm{Cu}$ concentration used to metallate APP124-189 on subsequent $\mathrm{Cu}$ toxicity was examined by pretreating the native protein $(50 \mu \mathrm{M})$ with increasing amounts of $\mathrm{Cu}$-Gly and measuring LDL oxidation. We observed maximum oxidative activity using $100 \mu \mathrm{M} \mathrm{Cu}-\mathrm{Gly}(\mathrm{Cu} /$ protein ratio of $2: 1)$, 


\section{Table 1. Peptides corresponding to the copper binding ectodomain (CuBD) of human APP and APP orthologs and paralogs}

Species Peptide Residues and sequence

Group 1: conserved central histidine region

$\begin{array}{ll}\text { Human APP } & \text { APP142-166 } \\ \text { Human APP } & \text { APP }_{\mathrm{CuBD}} \\ \text { Human APLP2 } & \text { APLP2 }_{\mathrm{CuBD}} \\ \text { F. rubripes } & \text { FuguAPP }_{\mathrm{CuBD}} \\ \text { Xenopus } & \text { XAPP }_{\mathrm{CuBD}} \\ \text { Group 2: nonconserved central histidine } & \text { region } \\ \text { Human APLP1 } & \text { APLP1 } \\ \text { N. japonica } & \text { elAPP }_{\mathrm{CuBD}} \\ \text { C. elegans } & \text { APL-1 } \\ \text { Drosophila } & \text { APPL } \\ & \end{array}$

whereas no detectable LDL oxidation was seen at concentrations of $\mathrm{Cu}-$ Gly below $25 \mu \mathrm{M}$ (Cu/protein ratio of 1:2) (Fig. $2 C$ ). To confirm that the toxicity of APP124-189-Cu involved generation of $\mathrm{Cu}(\mathrm{I})$, we measured protein-associated $\mathrm{Cu}(\mathrm{I})$ levels using the $\mathrm{BC}-\mathrm{Cu}(\mathrm{I})$ detection assay. Measurement of $\mathrm{Cu}$-metallated APP124-189 revealed a 10-fold greater absorbance when compared with nonmetallated APP124-189, whereas both $\mathrm{Cu}$ metallated and nonmetallated APP18-146, which lacks the $\mathrm{CuBD}$, revealed negligible absorbance readings after incubation with $\mathrm{BC}(* p<0.01)$ (Fig. $2 D)$. Importantly, these findings establish that the APP CuBD can induce significant neurotoxicity at physiological concentrations of both APP and $\mathrm{Cu}$.

Because the $\mathrm{ZnBD}$ is contained in APP124-189, the effect of $\mathrm{Zn}$ on APP $\mathrm{Cu}$ toxicity was measured. We treated $50 \mu \mathrm{M}$ APP124-189 with EDTA (1 mM) to remove any endogenously bound metals, as confirmed by ICP-MS, followed by dialysis and loading with either $\mathrm{Cu}$ or $\mathrm{Cu}+\mathrm{Zn}$. The $\mathrm{Cu}$-metallated APP124189 induced lower $\mathrm{Cu}$-mediated LPO when EDTA-treated protein was used [APP124-189-EDTA-Cu compared with nonEDTA-treated protein loaded with $\mathrm{Cu}$ (APP124-189-Cu) $(* * * p<0.05$ compared with APP124-189-Cu)] (Fig. 2B). The EDTA-treated APP124-189 loaded with both $\mathrm{Zn}$ and $\mathrm{Cu}$ (APP124-189-EDTA-Cu/Zn) restored LPO to maximum activity (Fig. $2 B$ ). These data indicate that $\mathrm{Zn}$ is not required to induce LPO by APP124-189-Cu but may have a structural role that can modulate $\mathrm{Cu}$ toxicity.

\section{Copper-mediated lipoprotein oxidation and neurotoxicity is induced by APP homologs expressing conserved histidine residues at positions 147, 149, and 151}

Previous studies have shown that the central histidine region (histidines 147, 149, and 151) of the APP CuBD is important for $\mathrm{Cu}(\mathrm{II})$ reduction (Multhaup et al., 1996; Ruiz et al., 1999; White et al., 1999a). To define the role of this region in APP toxicity, we examined two groups of APP homologs (Table 1). The first group contained a CuBD sequence from species with a conserved central histidine region but differed in their surrounding residues. Peptides corresponding to residues 135-166 of human APP were synthesized for human APLP2 (APLP2 $2_{\mathrm{CuBD}}$ ), Xenopus APP (xAP-

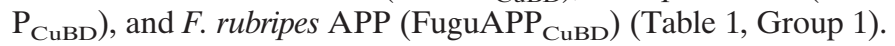
Each homolog significantly potentiated neuronal cell death in cultures exposed to $5 \mu \mathrm{M} \mathrm{Cu}$ (II) $\left({ }^{*} p<0.01\right)$ (Fig. $\left.3 A\right)$. LPO analysis revealed that $\mathrm{Cu}$-metallated $\mathrm{APLP} 2_{\mathrm{CuBD}}, \mathrm{xAPP}_{\mathrm{CuBD}}$, and FuguAPP ${ }_{\mathrm{CuBD}}$ all induced a significant increase in LDL oxidation $(138 \pm 4,140 \pm 4$, and $143 \pm 6 \%$, respectively) compared with LDL alone $(* p<0.01)$ (Fig. $3 B)$. These data strongly suggest that the conservation of the central histidine residues in the APP CuBD of diverse species preserves the ability to generate toxic-free radicals and promote neurotoxicity in the presence of $\mathrm{Cu}$.

The C. elegans APL-1 CuBD strongly protects against $\mathrm{Cu}$-induced lipoprotein oxidation and neurotoxicity

The second group of APP homologs examined (Table 1, Group 2) revealed single or multiple amino acid variations within the central histidine binding site but maintained the adjacent cysteines. Peptides corresponding to the human APP residues 135-166 were synthesized for APLP1 (APLP1 $\left.1_{\mathrm{CuBD}}\right)$, Drosophila APPL (APPL $\mathrm{CuBD})$, electric ray APP (elAPP $\left.{ }_{\mathrm{CuBD}}\right)$, and $C$. elegans APL-1 (APL-1 ${ }_{\text {CuBD }}$ ) (Table 1). The peptides were metallated with $\mathrm{Cu}(\mathrm{II})$ and tested for LPO activity. There was no change in LPO compared with LDL alone with any of the metallated peptides, whereas parallel treatment with human $\mathrm{APP}_{\mathrm{CuBD}} \mathrm{Cu}$ elevated LPO levels (Fig. $3 C$ ). Interestingly, the exposure of LDL to $20 \mu \mathrm{M} \mathrm{Cu}$-Gly with $140 \mu \mathrm{M}$ nonmetallated elAPP ${ }_{\mathrm{CuBD}}, \mathrm{APPL}_{\mathrm{CuBD}}$, or APL- $1_{\mathrm{CuBD}}$ peptide actually inhibited LDL oxidation by $\sim 20,40$, and $80 \%$, respectively $(* * p<0.05, * * * p<0.01$ ) (Fig. $3 D$ ). In contrast, 140 $\mu \mathrm{M}$ human $\mathrm{APP}_{\mathrm{CuBD}}$ or other Group 1 peptides increased LPO by a further $25 \%$ or more $\left({ }^{*} p<0.01\right.$ ) (Fig. $3 D$ ). Titration of APL$1_{\mathrm{CuBD}}$ against $20 \mu \mathrm{M} \mathrm{Cu}(\mathrm{II})$ revealed a clear dose-responsive protection by APL-1 $1_{\mathrm{CuBD}}$ (Fig. $3 E$ ).

To determine whether the ability to inhibit LPO by these APP homologs was reflected in increased neuronal survival against $\mathrm{Cu}$ toxicity, we treated cortical cultures with a toxic concentration of $\mathrm{Cu}(\mathrm{II})(10 \mu \mathrm{M})$ together with either $\mathrm{APPL}_{\mathrm{CuBD}}$ or APL-1 $1_{\mathrm{CuBD}}$ (two exposures at $70 \mu \mathrm{M}$ ). The APL-1 $1_{\text {CuBD }}$ peptide completely abrogated $\mathrm{Cu}$ toxicity to background levels $(0 \%)\left({ }^{* *} p<0.01\right)$ (Fig. $3 F$ ), whereas APPL $_{\mathrm{CuBD}}$ lowered $\mathrm{Cu}$-induced cell death from $20.1 \pm 0.9$ to $9.8 \pm 1.0 \%$. These findings demonstrate that C. elegans APL-1, and to a lesser extent the APPL CuBDs, has a potent inhibitory effect on $\mathrm{Cu}$ toxicity in vitro.

\section{Inhibition of $\mathrm{Cu}$-mediated lipid peroxidation by the APL-1 CuBD is mediated by tyrosine 147 and lysine 151}

Because the central histidines at positions 147, 149, and 151 are important for $\mathrm{APP}_{\mathrm{CuBD}} \mathrm{CuBD}$ activity, we proposed that the APL-1 protective phenotype would be caused by the sequence differences at the corresponding residues in $\mathrm{APL}-1_{\mathrm{CuBD}}$, which are tyrosine at 147 and lysine at 151 . To test this, mutagenesis studies were performed on the human $\mathrm{APP}_{\mathrm{CuBD}}$ and $C$. elegans APL- $1_{\mathrm{CuBD}}$. Human and $C$. elegans peptides were synthesized containing the amino acids of the opposing peptide at positions 147 and 151 (APP $_{\mathrm{CuBD}}$ Y147.K151 and APL-1 $\left.{ }_{\mathrm{CuBD}} \mathrm{H} 147 . \mathrm{H} 151\right)$ 
(Table 2). The numbering of the mutations in the APL- $1_{\mathrm{CuBD}}$ mutant peptides is based on the human APP sequence to simplify the presentation of the data (Table 2). Nonmetallated $\mathrm{APP}_{\mathrm{CuBD}}$ Y147.K151 was added to LDL $+20 \mu \mathrm{M} \mathrm{Cu}-$ Gly and inhibited $\mathrm{Cu}$-induced oxidation to a similar level as wild-type APL- $1_{\mathrm{CuBD}}\left({ }^{*} p<0.01\right)$ (Table 2$)$. Conversely, mutation of the Y147 and K151 residues in APL-1 to histidines, (APL$\left.1_{\mathrm{CuBD}} \mathrm{H} 147 . \mathrm{H} 151\right)$ converted it into a toxic peptide with an LPO activity similar to wild-type human $\mathrm{APP}_{\mathrm{CuBD}}\left({ }^{*} p<0.01\right)$ (Table 2). Single amino acid substitutions of either histidine 147 with tyrosine or histidine 151 with lysine $\left(\mathrm{APP}_{\mathrm{CuBD}} \mathrm{Y} 147\right.$ or $\left.\mathrm{APP}_{\mathrm{CuBD}} \mathrm{K} 151\right)$ (Table 2) produced inactive peptides that induced only background levels of LPO $(* p<0.01)$ (Table 2). Similarly, the single mutated APL-1 peptides APL- $1_{\mathrm{CuBD}} \mathrm{H} 147$ and APL$1_{\mathrm{CuBD}} \mathrm{H} 151$ revealed significantly reduced protective effects against $\mathrm{Cu}$ in nonmetallated peptide assays $\left({ }^{*} p<0.01\right)$ (Table 2$)$.

To examine whether the histidine-tyrosine and histidine-lysine substitutions could alter other APP homologs, we measured the LPO activity of APLP2 $2_{C u B D}$ Y147.K151 and $\mathrm{XAPP}_{\mathrm{CuBD}}$ Y147.K151. Consistent with the human APP ${ }_{C u B D}$ Y147.K151 results, these peptides also induced significantly protective effects similar to wild-type APL-1 $1_{\mathrm{CuBD}}$ in nonmetallated peptide assays $\left({ }^{*} p<0.01\right.$ compared with wild-type APLP $2_{\mathrm{CuBD}}$ and $\mathrm{xAPP} \mathrm{CuBD}_{\mathrm{Cu}}$ peptides) (Table 2). Because the APLP1 $1_{\mathrm{CuBD}}$ peptide is inactive, we also examined the effect of substituting the central histidines of human $\mathrm{APP}_{\mathrm{CuBD}}$ with the S147 and R149 present in APLP1 $1_{\mathrm{CuBD}}$. The APP ${ }_{\text {CuBD }}$ S147.R149.H151 peptide was inactive in the nonmetallated peptide assays $(* p<0.01$ compared with wild-type $\mathrm{APP}_{\mathrm{CuBD}}$ ) (Table 2). These findings demonstrated that the toxic and protective activities of the CuBD is dependent on the amino acids present in positions 147 and 151 in human APP or their equivalent position in APP orthologs and paralogs.

\section{The phenotype of the human APP and C. elegans APL- 1 CuBDs correlates with $\mathrm{Cu}$ (II) binding and reduction}

To understand the mechanism underlying the contrasting activities of the human $\mathrm{APP} \mathrm{CuBD}_{\mathrm{Cu}}$ and $\mathrm{APL}-1_{\mathrm{CuBD}}$ peptides, we used SPR to analyze specific binding to $\mathrm{Cu}(\mathrm{II})$ and determined the dissociation kinetics of the peptides (Table 3). Immobilized NTA on sensor chips in conjunction with SPR was used to assess directly the affinity of APP CuBD peptides for metal-ion binding. Our studies revealed that an intermediate ternary complex of NTA Cu(II) peptide is formed on the chip surface. The decreasing response signal (Fig. 4B, Displ. $k_{d}$ ), just before the real dissociation phase when the chip is washed with buffer, represents the dissociation of the complex when the peptide binding capacity of $\mathrm{Cu}$ (II) NTA is exceeded. The peptides exhibited displacement activities by competing with NTA for $\mathrm{Cu}$ (II) binding (A. Simons, T. Ruppert, C. Schmidt, A. Schlicksupp, R. Pipkorn, J. Reed, A. R. White, T. A. Bayer, C. L. Masters, R. Cappai, G. Multhaup, unpublished observations). The dissociation phases of three representative peptides are shown in Figure 4. Three peptides were examined: the $\mathrm{APP} \mathrm{P}_{\mathrm{CuBD}}$ peptide (toxic), $\mathrm{APLP} 1_{\mathrm{CuBD}}$ (inert), and APL-1 $1_{\text {CuBD }}$ (protective). The six sensorgrams were evaluated for mean dissociation rate constants. There was a clear difference between $\mathrm{APP}_{\mathrm{CuBD}}$ and $\mathrm{APL}-1_{\mathrm{CuBD}}$, with the latter showing higher maximum response units attributable to a higher affinity for the $\mathrm{Cu}$ (II) NTA chip surface (Table 3, Fig. 4B-E). These data indicate that $\mathrm{Cu}(\mathrm{II})$ binding and reduction are affected by the amino acid side chains at positions 147 and 151, correlating with the toxic or protective phenotypes.

When the peptides were injected in the presence of $10 \mu \mathrm{M}$
$\mathrm{Cu}(\mathrm{I})$-specific chelator BC (Fig. 4B-D, bold curves), the maximum response increased threefold for $\mathrm{APP}_{\mathrm{CuBD}}$ but remained unchanged for the inert and protective peptides (Fig. 4E). The displacement of the ternary complex was unaffected for $\mathrm{APP} \mathrm{CuBD}_{\mathrm{Cu}}$ (Fig. $4 B$ ) and APL- $1_{\mathrm{CuBD}}$ (Fig. 4D) but increased twofold for $\mathrm{APLP}_{\mathrm{CuBD}}$ (Fig. $4 C$ ). The dissociation from NTA Cu(II) was specifically decreased for $\mathrm{APP}_{\mathrm{CuBD}}$ (Fig. $4 B$ ) in the presence of $\mathrm{BC}$ when compared with the other peptides (Fig. $4 C, D$ ) that do not show significant alterations in their dissociation constants. These data clearly show that $\mathrm{BC}$ increases the $\mathrm{Cu}$ (II) binding capacity of $A P P_{C u B D}$ but not of APLP1 $1_{C u B D}$ or APL-1 $1_{C u B D}$ (Fig. $4 E$ ). APL- $1_{\mathrm{CuBD}}$ was the most effective in $\mathrm{Cu}(\mathrm{II})$ binding, and its maximal binding remained unaffected by $\mathrm{BC}$.

These kinetic results suggest that $\mathrm{APP}_{\mathrm{CuBD}}$ reduces $\mathrm{Cu}(\mathrm{II})$ NTA as fast as it binds to $\mathrm{Cu}$ (II) NTA. After reduction, $\mathrm{Cu}(\mathrm{I})$ is immediately released from the NTA (Simons, Ruppert, Schmidt, Schlicksupp, Pipkorn, Reed, White, Masters, Cappai, Multhaup, unpublished observations), most likely as an $\mathrm{APP}_{\mathrm{CuBD}} \mathrm{Cu}(\mathrm{I})$ complex. This is supported by our earlier study analyzing $\mathrm{Cu}$ binding of $\mathrm{APP}_{\mathrm{CuBD}}$ by liquid chromatography electrospray ionization mass spectrometry (Multhaup et al., 1996). We could identify APP $\mathrm{Cu}$ complexes without being able to differentiate between $\mathrm{Cu}$ (II) and $\mathrm{Cu}(\mathrm{I})$ binding. The rate of $\mathrm{Cu}(\mathrm{II})$ to $\mathrm{Cu}(\mathrm{I})$ reduction by $\mathrm{APLP} 1_{\mathrm{CuBD}}$ seems to be much slower, because maximum binding was reached first before $\mathrm{Cu}(\mathrm{II})$ was reduced and peptide $\mathrm{Cu}(\mathrm{I})$ complexes were displaced from the NTA surface. This is in agreement with previous results showing that the APLP1 peptide has significantly less ability to produce $\mathrm{Cu}(\mathrm{I})$ as measured by the BC assay (Multhaup et al., 1996). There was no significant difference in the displacement of the ternary complex including APL-1 $1_{\mathrm{CuBD}}$ in the presence or absence of BC (Fig. $4 D$ ). The slight difference between both constants (Table 3) derived from Figure $4 D$ might be attributable to the Cu-reducing activity of APL-1 $1_{\mathrm{CuBD}}$ being lower than for APLP1 $1_{\mathrm{CuBD}}$ or being totally absent. These data indicate that the toxic phenotype of the $\mathrm{CuBD}$ peptides examined here correlates with $\mathrm{Cu}$ (II) binding and reduction kinetics. The toxic activity of human $\mathrm{APP}_{\mathrm{CuBD}}$ may reflect lower $\mathrm{Cu}(\mathrm{II})$ binding and high $\mathrm{Cu}(\mathrm{II})$ reduction, whereas protection by APL- $1_{\mathrm{CuBD}}$ is mediated through high $\mathrm{Cu}(\mathrm{II})$ binding and limited $\mathrm{Cu}(\mathrm{II})$ reduction.

\section{DISCUSSION}

A growing body of data supports a significant role for redox active metals, such as $\mathrm{Cu}$ and $\mathrm{Fe}$, as key modulators of the pathogenic pathways that underlie neurodegenerative disorders (for review, see Waggoner et al., 1999; Bush, 2000; Sayre et al., 2000). A delineation of the interactions between these metals and their molecular partners is needed to understand their role in the disease process. In relation to $\mathrm{AD}$, the interaction among $\mathrm{Cu}$, $\mathrm{APP}$, and $\mathrm{A} \beta$ can result in ROI generation and subsequent oxidative stress. We have shown that APP-deficient neurons have increased resistance to $\mathrm{Cu}$ toxicity and that a $\mathrm{CuBD}$ peptide can induce toxicity from $\mathrm{Cu}$ added to culture medium (White et al., 1999a). In vivo studies have revealed increased $\mathrm{Cu}$ levels in brain and liver of APP $-/-$ mice, and we have observed alterations to $\mathrm{Cu}$ metabolism in a transgenic mouse model of AD that expresses high levels of human APP (our unpublished observations). These data demonstrate an important role for APP in $\mathrm{Cu}$ homeostasis. The present findings, however, provide unequivocal evidence that the full-length APP molecule can induce neurotoxicity at physiologically relevant concentrations of APP and $\mathrm{Cu}$. Both membrane-associated and soluble APP purified from human 
A
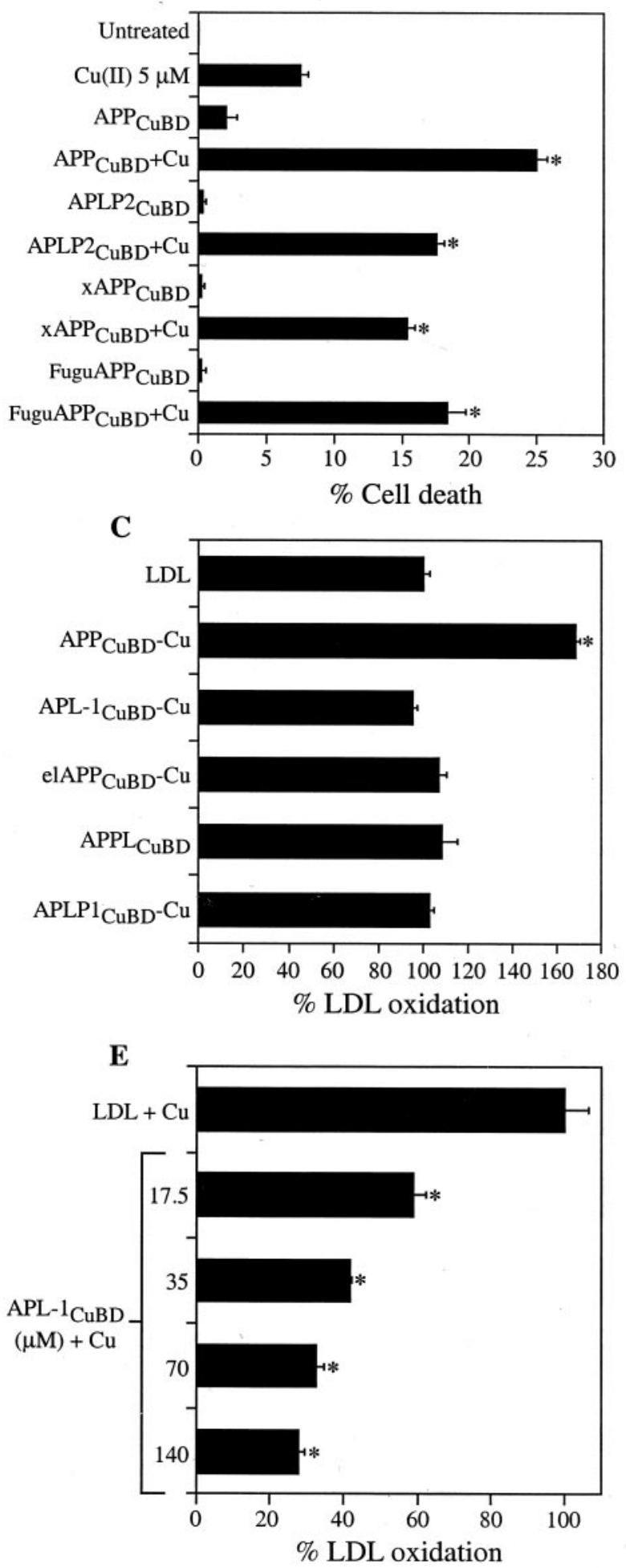

B
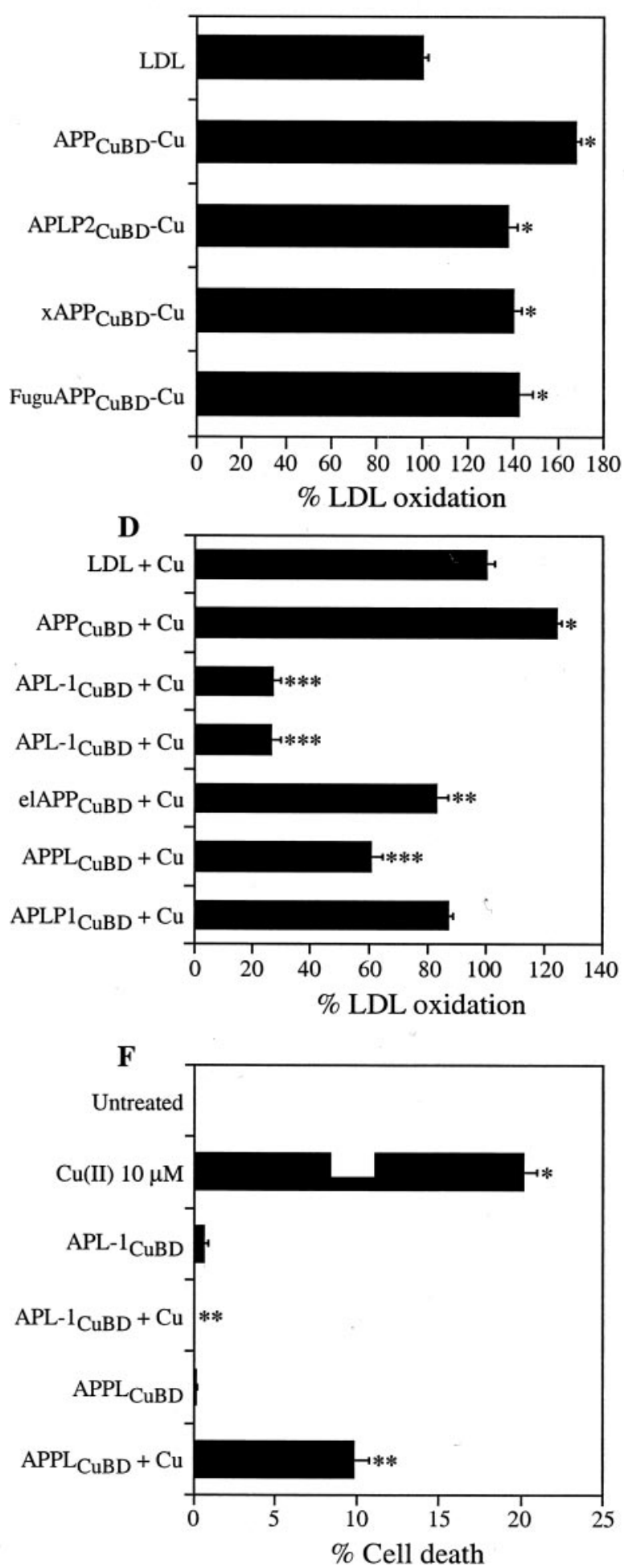

Figure 3. A, Cell death induced by APP CuBD homologs with a highly conserved central histidine region. Primary cortical neurons were incubated with subtoxic $\mathrm{Cu}(\mathrm{II})(5 \mu \mathrm{M})$ and $70 \mu \mathrm{M}$ nonmetallated $\mathrm{APP}_{\mathrm{CuBD}}$, APLP2 ${ }_{\mathrm{CuBD}}$, xAPP ${ }_{\mathrm{CuBD}}$, or FuguAPP $\mathrm{CuBD}$ ( 2 exposures of each over $\left.4 \mathrm{~d}\right)$. Cell death was determined with the LDH assay. All peptides induced significantly elevated neuronal cell death compared with Cu or peptides alone $\left({ }^{*} p<0.01\right)$. $B, \mathrm{LDL}$ oxidation induced by APP CuBD homologs with a highly conserved central histidine region. LDL ( $0.5 \mathrm{mg} / \mathrm{ml})$ was incubated with $\mathrm{APP}$ CuBD or with the APP homologs APLP2 $2_{\mathrm{CuBD}}$, xAPP $\mathrm{CuBD}_{\mathrm{C}}$, or FuguAPP $\mathrm{CuBD}(50 \mu \mathrm{M})(\mathrm{Cu}$ metallated $)$. All peptides induced significant increases in LDL oxidation compared with LDL alone $\left({ }^{*} p<0.01\right)$. $C$, LDL oxidation induced by APP CuBD homologs with a nonconserved central histidine region. LDL ( 0.5

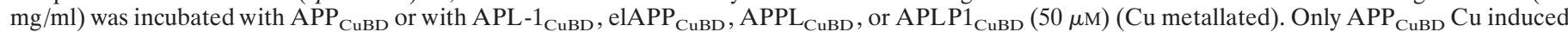
significantly elevated LDL oxidation $\left({ }^{*} p<0.01\right)$. $D$, Effect of APP CuBD homologs on LDL oxidation induced by Cu-Gly. LDL $(0.5 \mathrm{mg} / \mathrm{ml})$ was incubated with $20 \mu \mathrm{M} \mathrm{Cu}$-Gly with or without nonmetallated APP CuBD peptides $(140 \mu \mathrm{M})$. APP $_{\mathrm{CuBD}}$ induced a significant (Figure legend continues) 

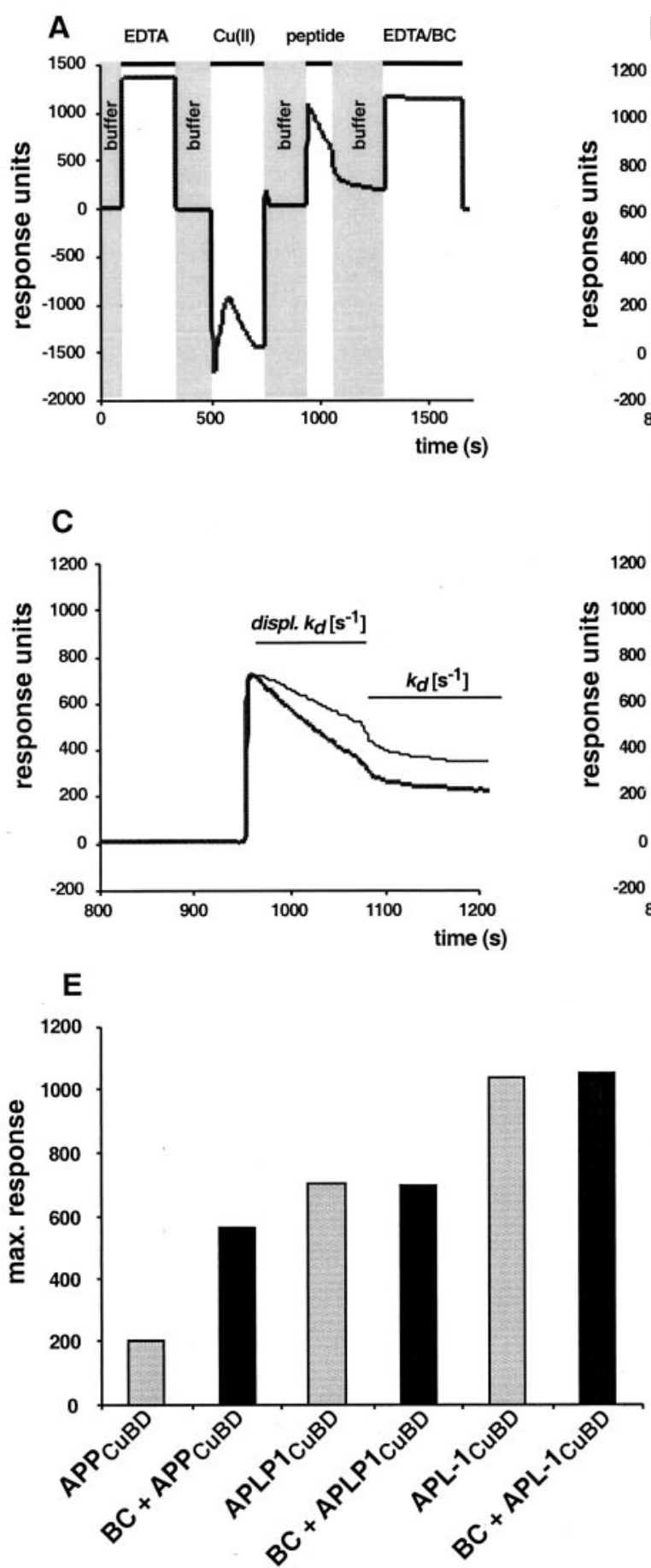

brain as well as recombinant APP ectodomain induced $\mathrm{Cu}(\mathrm{I})$ mediated LPO in vitro. These findings contrast with previous studies demonstrating neuroprotective and neuritogenic activity for soluble APP (Milward et al., 1992; Mattson et al., 1993; Small
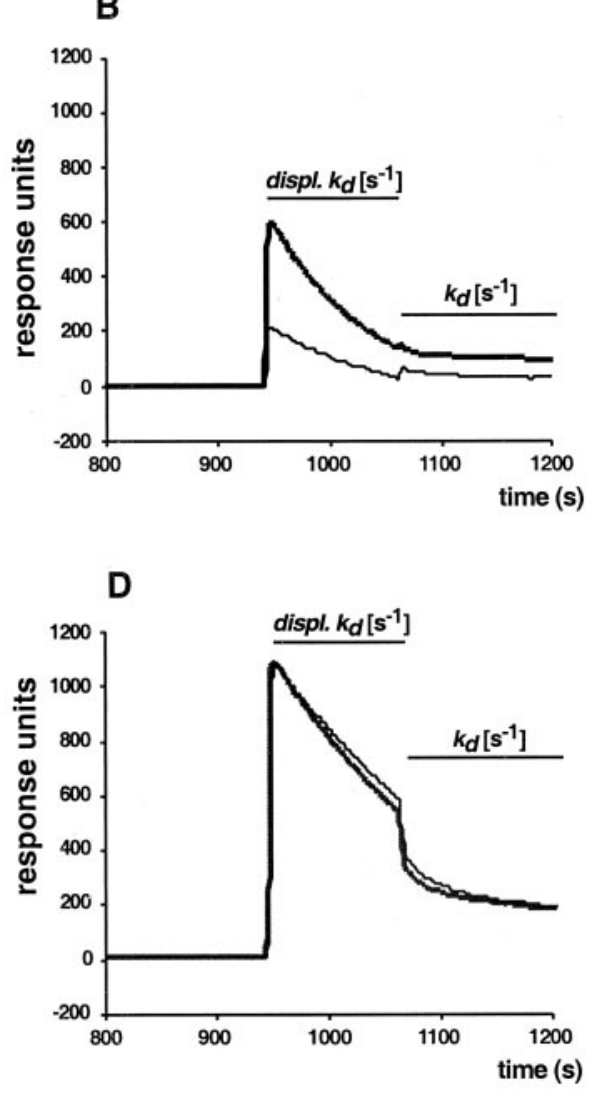

Figure 4. A, Sensorgram showing the profile for the sensor surface treatment for the cycle of $\mathrm{APP}_{\mathrm{CuBD}}$ peptide (and of its derivatives) binding to an NTA sensor chip and its regeneration with EDTA/BC. The profile shows that an intermediate ternary complex of NTA $\mathrm{Cu}(\mathrm{II})$ peptide is formed (peptide). $B, C, D$, The dissociation kinetics for $\mathrm{APP}_{\mathrm{CuBD}}(B)$, $\operatorname{APLP}_{\mathrm{CuBD}}(C)$, and APLP1 $1_{\mathrm{CuBD}}$ is interpreted as the displacement of peptide $\mathrm{Cu}(\mathrm{I})$ complexes from the sensor surface (displ. $K_{d}$ ) and peptide elution from the $\mathrm{Cu}(\mathrm{II})$ NTA surface $\left(K_{d}\right)(D)$. The bold dark line represents the peptides being injected in the presence of $10 \mu \mathrm{M}$ of the $\mathrm{Cu}(\mathrm{I})$-specific chelator $\mathrm{BC}$. The thin line represents the peptides being injected in the presence of running buffer. $E$, Maximum response units were reached at 980 sec and taken from the curves in $B, C$, and $D$ obtained in the presence of running buffer (gray bars) or BC (black bars).

\section{$\leftarrow$}

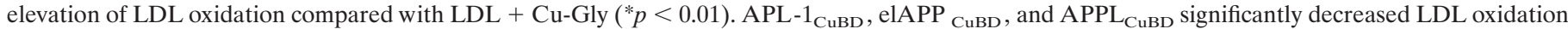
induced by Cu-Gly $\left({ }^{* *} p<0.05,{ }^{* * *} p<0.01\right)$, whereas APLP1 $1_{\mathrm{CuBD}}$ had no significant effect on LDL oxidation. $E$, Effect of APL- $1_{\mathrm{CuBD}}$ on LDL oxidation induced by $\mathrm{Cu}-\mathrm{Gly}$. LDL was incubated with $20 \mu \mathrm{M} \mathrm{Cu}$-Gly with or without APL- $1_{\mathrm{CuBD}}(17.5-140 \mu \mathrm{M})$. APL-1 $1_{\mathrm{CuBD}}$ induced a dose-dependent decrease in $\mathrm{Cu}$-Gly-mediated LDL oxidation $\left({ }^{*} p<0.01\right) . F$, Effect of APL- $1_{\mathrm{CuBD}}$ and $\mathrm{APPL}_{\mathrm{CuBD}}$ on Cu-induced neuronal cell death. Primary cortical neurons were incubated with a toxic concentration of Cu-Gly $(10 \mu \mathrm{M})(* p<0.01)$ with or without APL- $1_{\mathrm{CuBD}}$ or $\mathrm{APPL}_{\mathrm{CuBD}}(70 \mu \mathrm{M})(2$ treatments of each over

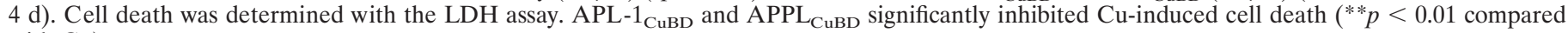
with $\mathrm{Cu}$ ).

et al., 1994; Cappai et al., 1999). However, the difference can be explained by the need to metallate $\mathrm{Cu}$ to APP to mediate neurotoxic effects because nonmetallated did not induce LPO or neuronal cell death in this study. 


\begin{tabular}{|c|c|c|c|}
\hline $\mathrm{LDL}+\mathrm{Cu}(\mathrm{II})+$ peptide $^{a}$ & Sequence & $\begin{array}{l}\mathrm{LPO} \\
(\% \text { of } \mathrm{LDL}+\mathrm{Cu})\end{array}$ & $\begin{array}{l}\mathrm{Cu} \\
\text { activity }\end{array}$ \\
\hline \multirow[t]{2}{*}{ No peptide } & & $100 \pm 3$ & \\
\hline & $147 \quad 151$ & & \\
\hline Wild-type $\mathrm{APP}_{\mathrm{CuBD}}$ & FLHQERMDVCETHLHWHTVAKETCSEKSTNLH & $124 \pm 2$ & Toxic \\
\hline $\mathrm{APP}_{\mathrm{CuBD}} \mathrm{Y} 147 . \mathrm{K} 151$ & FLHQERMDVCETYLHWKTVAKETCSEKSTNLH & $41 \pm 2^{*}$ & Protective \\
\hline Wild-type APL-1 $1_{\mathrm{CuBD}}$ & FSHVNSRDQCNDYQHWKDEAGKQCKTKKSKGN & $27 \pm 3$ & Protective \\
\hline APL-1 ${ }_{\mathrm{CuBD}} \mathrm{H} 147 . \mathrm{H} 151$ & FSHVNSRDQCND HQHWHDEAGKQCKTKKSKGN & $135 \pm 3^{*}$ & Toxic \\
\hline $\mathrm{APP}_{\mathrm{CuBD}} \mathrm{Y} 147$ & FLHQERMDVCETYLHWHTVAKETCSEKSTNLH & $94 \pm 2^{*}$ & Inert \\
\hline $\mathrm{APP}_{\mathrm{CuBD}} \mathrm{K} 151$ & FLHQERMDVCETHLHWKTVAKETCSEKSTNLH & $87 \pm 3^{*}$ & Inert \\
\hline APL-1 ${ }_{\mathrm{CuBD}} \mathrm{H} 151$ & FSHVNSRDQCNDYQHWHDEAGKQCKTKKSKGN & $70 \pm 6^{*}$ & Inert \\
\hline APL-1 ${ }_{\mathrm{CuBD}} \mathrm{H} 147$ & FSHVNSRDQCND $\underline{H Q H W K D E A G K Q C K T K K S K G N ~}$ & $72 \pm 5^{*}$ & Inert \\
\hline Wild-type APLP $2_{\mathrm{CuBD}}$ & FFHKERMEVCENHQHWHTVVKEACLTQGMTLY & $136 \pm 11$ & Toxic \\
\hline APLP2 ${ }_{\mathrm{CuBD}}$ Y147.K151 & FFHKERMEVCENYQHWKTVVKEACLTQGMTLY & $45 \pm 2^{*}$ & Protective \\
\hline Wild-type $\mathrm{xAPP}_{\mathrm{CuBD}}$ & FLHQERMD ICETHLHWHTVAKESCSEKSMSLH & $125 \pm 3$ & Toxic \\
\hline $\mathrm{xAPP}_{\mathrm{CuBD}} \mathrm{Y} 147 . \mathrm{K} 151$ & FLHQERMD ICETYLHWKTVAKESCSEKSMSLH & $47 \pm 2^{*}$ & Protective \\
\hline Wild-type APLP1 $1_{\text {CuBD }}$ & FLHQERMDQCESSTRRHQEAQEACSSQGLILH & $87 \pm 2$ & Inert \\
\hline $\mathrm{APP}_{\mathrm{CuBD}} \mathrm{S} 147 . \mathrm{R} 149$ & FLHQERMDVCETSLRWHTVAKETCSEKSTNLH & $90 \pm 9^{*}$ & Inert \\
\hline
\end{tabular}

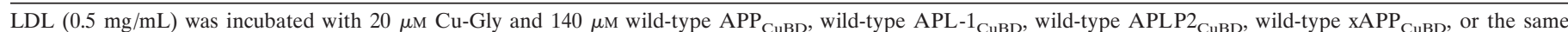

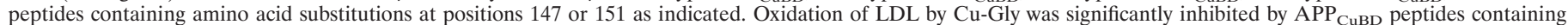

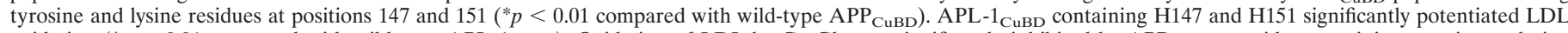

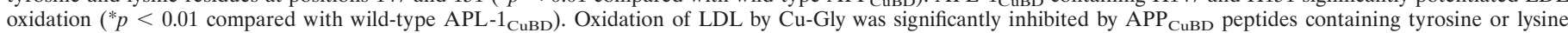

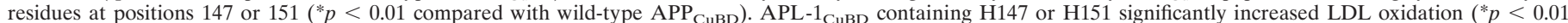

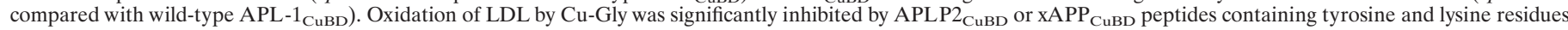

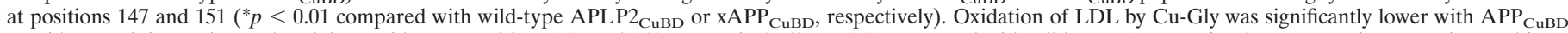

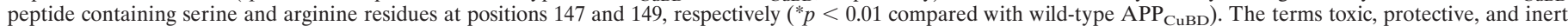
broadly indicate the activity of the peptides toward $\mathrm{Cu}$-mediated LPO.

${ }^{a}$ Numbering of mutations is based on human APP sequence.

In vivo, cell-associated APP $\mathrm{Cu}$ could induce neurotoxicity through its prolonged exposure on the surface of neurites (Storey et al., 1999) and its juxtaposition to membrane lipids, whereas soluble APP directly binds to neuronal membrane receptors and to fibrillar $\mathrm{A} \beta$ on the cell surface (Melchor and Van Nostrand, 2000). The interaction of APP $\mathrm{Cu}$ with lipoproteins provides an additional mechanism for APP-mediated neurotoxicity. Whether APP $\mathrm{Cu}$ is able to induce direct or oxidized lipoprotein-mediated neuronal damage in vivo would depend on the availability of both $\mathrm{Cu}$ and lipoproteins. A potential role for oxidized lipoproteins in mediating neurodegeneration is supported by LDL being present in the brain as a result of cholesterol metabolism (Keller et al., 1999, 2000), whereas high-density lipoprotein (HDL) is synthesized by glial cells and associated with amyloid plaques in AD (Harr et al., 1996; Markesbery, 1997; Yamada et al., 1997). In addition, the expression of the apolipoprotein E4, a risk factor for AD, can promote APP secretion (Howland et al., 1998). Interestingly, lipoproteins derived from AD CSF fluid reveal a higher level of oxidation than control lipoproteins (Bassett et al., 1999,

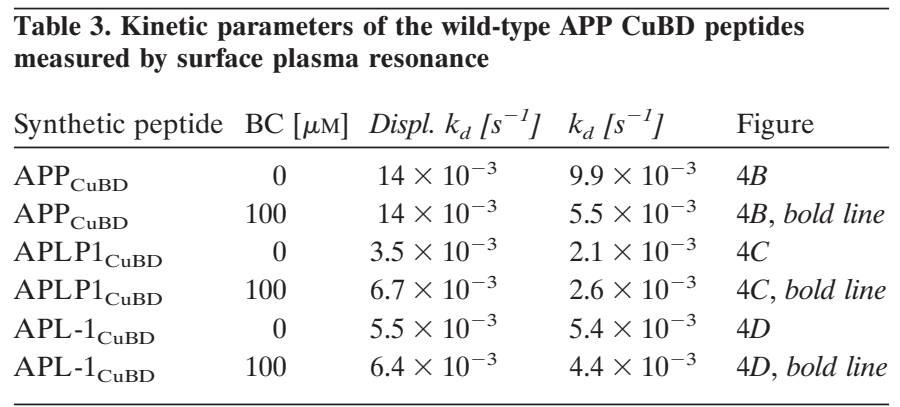

2000; Schippling et al., 2000) and Cu-oxidized LDL and HDL induce neuronal cell death in vitro (Dubbing 1963; Kabara 1973; Pitas et al., 1987; Keller et al., 1999, 2000). Significantly, cerebral cortex and hippocampus from a transgenic mouse model of AD amyloidosis reveal increased LPO compared with wild-type mice well before the appearance of $\mathrm{A} \beta$ plaques (Praticò et al., 2001). Our finding that APP $\mathrm{Cu}$ can induce LDL oxidation and subsequent neuronal death in vitro suggests that similar mechanisms could mediate oxidative damage in AD.

A key finding from this study came from the analysis of the CuBD from different species and APP family members. We showed that the amino acids at positions 147 and 151 of the central histidine region can dramatically influence the activity of the CuBD. This is supported by Ruiz et al. (1999) who showed that $\mathrm{Cu}$ reduction was diminished in mutant APP147-151 peptides with histidine-alanine substitutions. APP homologs with conserved histidine residues at positions 147 and 151 all induced significant neurotoxicity. However, the APLP1, APL-1, APPL, and elAPP genes all contained different residues within the histidine region and consequently revealed nontoxic or protective activities in the presence of $\mathrm{Cu}$. Particularly striking was the high level of protection against $\mathrm{Cu}$ toxicity afforded by $\mathrm{APL}-1_{\mathrm{CuBD}}$. The substitution of the APL-1 Y147 and K151 for histidines, as found in all toxic APP homologs, completely reversed the APL-1 phenotype from protective to toxic. Conversely, substitution of H147 and H151 for tyrosine and lysine in human APP, APLP2, or XAPP resulted in a protective phenotype, whereas human $\mathrm{APP}_{\mathrm{CuBD}}$ was converted into an inert phenotype by substituting histidine 147 for serine and histidine 149 for arginine as present in APLP1. Biophysical analysis suggested that the mechanism responsible for the human and $C$. elegans phenotypes could be 
correlated to the $\mathrm{Cu}$ binding and reduction activity of the peptides. There was a clear distinction in these activities between the human and $C$. elegans sequences and the inert APLP1 peptide having an intermediate value. This demonstrates that residues 147 and 151 can markedly influence APP Cu chemistry, although these studies will need to be extended to all APP homologs to confirm the findings. Significantly, the CuBD of human APP is able to modulate both $\mathrm{Cu}$ neurotoxicity, as shown here, and $\mathrm{A} \beta$ production (Borchardt et al., 2000). Our studies identify histidines 147 and 151 as key targets for therapeutic modulation of these toxic processes.

The species differences may reflect significant evolutionary changes in APP Cu chemistry. Our data support a general evolutionary trend toward a decreased need for $\mathrm{Cu}$ protection in higher order species. Alternatively, there is a gain in activity toward promoting $\mathrm{Cu}(\mathrm{II})$ reduction. APP (including APLP2) from humans, Xenopus, and pufferfish induces significant $\mathrm{Cu}$ toxicity, whereas APP from lower order species (Drosophila, electric ray, and C. elegans) either has little effect on $\mathrm{Cu}$ toxicity or is protective. Although APLP1 has no net effect on $\mathrm{Cu}$ toxicity and is expressed in humans, this molecule is considered to be the ancestral form of APP (Coulson et al., 2000). The general increase in APP $\mathrm{Cu}$ toxicity of higher order species may reflect a decrease in environmental $\mathrm{Cu}$ levels or adaptation of additional mechanisms for detoxifying $\mathrm{Cu}$, such as ceruloplasmin and transcuprein. The APP CuBD may have a function in sensing and responding to environmental (extracellular) $\mathrm{Cu}$, a hypothesis supported by the fact that cells transfected with human APP cDNA can respond to increased $\mathrm{Cu}$ levels by enhancing APP secretion (Borchardt et al., 1999), and APP-/- mice have increased Cu levels in brain and liver (White et al., 1999b). This is further supported by neurons from $C$. elegans being involved in sensing and avoiding $\mathrm{Cu}$ (Sambongi et al., 1999). Whether APL-1 is involved in this process is unknown. APP could also act as a cell membrane $\mathrm{Cu}(\mathrm{II})$ reductase similar to Fre1 in yeast (Hassett and Kosman, 1995; Georgatsou et al., 1997) providing $\mathrm{Cu}(\mathrm{I})$ for subsequent uptake by $\mathrm{Cu}$ transport proteins or delivery to a recipient cuproprotein. This in turn could shift APP processing toward secretion to enhance $\mathrm{Cu}$ removal.

Regardless of the primary function of APP $\mathrm{Cu}$ reduction, it is clear that perturbations to $\mathrm{Cu}$ and/or APP metabolism can potentially result in $\mathrm{Cu}(\mathrm{I})$-mediated neurotoxicity from cellassociated or soluble APP (Multhaup et al., 1998; White et al., 1999a). Amyloidogenic A $\beta$ can mediate APP and APLP2 accumulation (Cribbs et al., 1995; Schmitt et al., 1997; White et al., 1998) and could result in Cu-mediated toxicity, particularly if associated with additional changes to $\mathrm{Cu}$ or lipoprotein metabolism (Keller et al., 1999, 2000). Our findings may also have implications for other neurodegenerative disorders such as amyotrophic lateral sclerosis (ALS). Motor neuron loss, in some familial cases of ALS, involves point mutations that promote the interaction of aggregated superoxide dismutasebound $\mathrm{Cu}$ with exogenous molecules, resulting in free radical toxicity (Yim et al., 1996; Waggoner et al., 1999; Azzouz et al., 2000). Our work supports this hypothesis by showing that altering the $\mathrm{Cu}$ chemistry of a redox active protein can markedly increase its oxidative potential. Further studies are needed to determine the role of APP $\mathrm{Cu}$ interactions in vivo and whether aberrant generation of $\mathrm{Cu}(\mathrm{I})$ by APP contributes to the neurodegenerative process in $\mathrm{AD}$.

\section{REFERENCES}

Andrews NC (2001) Mining copper transport genes. Proc Natl Acad Sci USA 98:6543-6545.

Atwood CS, Moir RD, Huang XD, Scarpa RC, Bacarra NME, Romano DM, Hartshorn MK, Tanzi RE, Bush AI (1998) Dramatic aggregation of Alzheimer A-beta by Cu (II) is induced by conditions representing physiological acidosis. J Biol Chem 273:12817-12826.

Azzouz M, Poindron P, Guettier S, Leclerc N, Andres C, Warter JM, Borg J (2000) Prevention of mutant SOD1 motoneuron degeneration by copper chelators in vitro. J Neurobiol 42:49-55.

Bassett CN, Montine KS, Neely MD, Swift LL, Montine TJ (2000) Cerebrospinal fluid lipoproteins in Alzheimer's disease. Microsc Res Tech 50:282-286.

Bassett CN, Neely MD, Sidell KR, Markesbery WR, Swift LL, Montine TJ (1999) Cerebrospinal fluid lipoproteins are more vulnerable to oxidation in Alzheimer's disease and are neurotoxic when oxidized $e x$ vivo. Lipids 34:1273-1280.

Borchardt T, Camakaris J, Cappai R, Masters CL, Beyreuther K, Multhaup $\mathrm{G}$ (1999) Copper inhibits beta-amyloid production and stimulates the non-amyloidogenic pathway of amyloid-precursor-protein secretion. Biochem J 344:461-467.

Borchardt T, Schmidt C, Camakaris J, Cappai R, Masters CL, Beyreuther K, Multhaup G (2000) Differential effects of zinc on amyloid precursor protein (APP) processing in copper-resistant variants of cultured Chinese hamster ovary cells. Cell Mol Biol 46:785-795.

Bush AI (2000) Metals and neuroscience. Curr Opin Chem Biol 4:184-191.

Cappai R, Mok SS, Galatis D, Tucker DF, Henry A, Beyreuther K, Small DH, Masters CL (1999) Recombinant human amyloid precursor-like protein 2 (APLP2) expressed in the yeast Pichia pastoris can stimulate neurite outgrowth. FEBS Lett 442:95-98.

Carpino LA, Han GY (1972) The 9-fluorenylmethoxycarbonyl amino protecting group. J Org Chem 37:3404-3409.

Cherny RA, Legg JT, McLean CA, Fairlie D, Huang X, Atwood CS, Beyreuther K, Tanzi RE, Masters CL, Bush AI (1999) Aqueous dissolution of Alzheimer's disease A $\beta$ amyloid deposits by biometal depletion. J Biol Chem 274:23223-23228.

Coulson EJ, Paliga K, Beyreuther K, Masters CL (2000) What the evolution of the amyloid protein precursor supergene family tells us about its function. Neurochem Int 36:175-184.

Cribbs DH, Davis-Salinas J, Cotman CW, Van Nostrand WE (1995) Ab induces increased expression and processing of amyloid precursor protein in cortical neurons. Alzheimer's Res 1:197-200.

Daigle I, Li C (1993) APL-1, a Caenorhabditis elegans gene encoding a protein related to the human beta-amyloid protein precursor. Proc Natl Acad Sci USA 90:12045-12049.

Dubbing A (1963) The entry of cholesterol into rat brain during development. J Neurochem 10:739-742.

Georgatsou E, Mavrogiannis LA, Fragiadakis GS, Alexandraki D (1997) The yeast Fre1P/Fre2P cupric reductases facilitate copper uptake and are regulated by the copper-modulated Mac1P activator. J Biol Chem 272:13786-13792.

Glenner GG, Wong CW (1984) Alzheimer's disease and Down's syndrome: sharing of a unique cerebrovascular amyloid fibril protein. Biochem Biophys Res Commun 122:1131-1135.

Hardy J, Duff K, Hardy KG, Perez-Tur J, Hutton M (1998) Genetic dissection of Alzheimer's disease and related dementias: amyloid and its relationship to tau. Nat Neurosci 1:355-358.

Harr SD, Uint L, Hollister R, Hyman BT, Mendez AJ (1996) Brain expression of apolipoproteins E, J, and A-I in Alzheimer's disease. J Neurochem 66:2429-2435.

Hassett R, Kosman DJ (1995) Evidence for $\mathrm{Cu}(\mathrm{II})$ reduction as a component of copper uptake by Saccharomyces cerevisiae. J Biol Chem 270:128-134.

Henry A, Masters CL, Beyreuther K, Cappai R (1997) Expression of the ectodomains of the human amyloid precursor protein in Pichia pastoris: analysis of culture conditions, purification, and characterization. Protein Expr Purif 10:283-291.

Henry A, Li QX, Galatis D, Hesse L, Multhaup G, Beyreuther K, Masters CL, Cappai R (1998) Inhibition of platelet activation by the Alzheimer's disease amyloid precursor protein. Br J Haematol 103:402-415.

Hesse L, Beher D, Masters CL, Multhaup G (1994) The bA4 amyloid precursor protein binding to copper. FEBS Lett 349:109-116.

Howland DS, Trusko SP, Savage MJ, Reame AG, Lang DM, Hirsch JD, Maeda N, Siman R, Greenberg BD, Scott RW, Flood DG (1998) Modulation of secreted beta-amyloid precursor protein and amyloid beta-peptide in brain by cholesterol. J Biol Chem 273:16576-16582.

Huang X, Atwood CS, Cuajungco MP, Hartshorn MA, Tyndall J, Hanson GR, Stokes KC, Leopold M, Multhaup G, Goldstein LE, Scarpa RC, Saunders AJ, Lim J, Moir RD, Glabe C, Bowden EF, Masters CL, Fairlie DP, Tanzi RE, Bush AI (1999a) Cu(II) potentiation of Alzheimer $\mathrm{A} \beta$ neurotoxicity: correlation with cell-free hydrogen peroxide production and metal reduction. J Biol Chem 274:37111-37116.

Huang X, Atwood CS, Hartshorn MA, Multhaup G, Goldstein LE, 
Scarpa RC, Cuajungco MP, Gray DN, Lim J, Moir RD, Tanzi RE, Bush AI (1999b) The A $\beta$ peptide of Alzheimer's disease directly produces hydrogen peroxide through metal ion reduction. Biochemistry 38:7609-7616.

Iijima K, Lee DS, Okutsu J, Tomita S, Hirashima N, Kirino Y, Suzuki T (1998) cDNA isolation of Alzheimer's amyloid precursor protein from cholinergic nerve terminals of the electric organ of the electric ray. Biochem J 330:29-33.

Kabara JJ (1973) A critical review of cholesterol metabolism. Prog Brain Res 40:363-382.

Kang J, Lemaire H, Unterbeck A, Salbaum JM, Masters CL, Grzeschik K, Multhaup G, Beyreuther K, Müller-Hill B (1987) The precursor of Alzheimer's disease amyloid A4 protein resembles a cell-surface receptor. Nature 325:733-736.

Keller JN, Hanni KB, Markesbery WR (1999) Oxidized low-density lipoprotein induces neuronal death: implications for calcium, reactive oxygen species, and caspases. J Neurochem 72:2601-2609.

Keller JN, Hanni KB, Kindy MS (2000) Oxidized high-density lipoprotein induces neuron death. Exp Neurol 161:621-630.

Koh J, Yang LL, Cotman CW (1990) $\beta$-Amyloid protein increases the vulnerability of cultured cortical neurons to excitotoxic damage. Brain Res 533:315-320.

Lovell MA, Robertson JD, Teesdale WJ, Campbell JL, Markesbery WR (1998) Copper, iron and zinc in Alzheimer's disease senile plaques. J Neurol Sci 158:47-52.

Markesbery WR (1997) Oxidative stress hypothesis in Alzheimer's disease. Free Radic Biol Med 23:134-147.

Martins RN, Harper CG, Stokes GB, Masters CL (1986) Increased cerebral glucose-6-phosphate dehydrogenase activity in Alzheimer's disease may reflect oxidative stress. J Neurochem 46:1042-1045.

Masters CL, Simms G, Weinman NA, Multhaup G, McDonald BL, Beyreuther K (1985) Amyloid plaque core protein in Alzheimer disease and Down syndrome. Proc Natl Acad Sci USA 82:4245-4249.

Mattson MP, Cheng B, Culwell AR, Esch FS, Lieberburg I, Rydel RE (1993) Evidence for excitoprotective and intraneuronal calciumregulating roles for secreted forms of the $\beta$-amyloid precursor protein. Neuron 10:243-254.

Melchor JP, Van Nostrand WE (2000) Fibrillar amyloid beta-protein mediates the pathologic accumulation of its secreted precursor in human cerebrovascular smooth muscle cells. J Biol Chem 275:9782-9791.

Merrifield RB (1963) The synthesis of a tetrapeptide. J Am Chem Soc 85:2149-2154.

Milward E, Papadopoulos R, Fuller SJ, Moir RD, Small D, Beyreuther K, Masters CL (1992) The amyloid protein precursor of Alzheimer's disease is a mediator of the effects of nerve growth factor on neurite outgrowth. Neuron 9:129-137.

Moir RD, Martins RN, Small DH, Bush AI, Milward EA, Multhaup G, Beyreuther K, Masters CL (1992) Human brain BA4 amyloid protein precursor (APP) of Alzheimer's disease: purification and partial characterization. J Neurochem 59:1490-1498.

Multhaup G, Schlicksupp A, Hesse L, Beher D, Ruppert T, Masters CL, Beyreuther K (1996) The amyloid precursor protein of Alzheimer's disease in the reduction of copper (II) to copper (I). Science 271:1406-1409.

Multhaup G, Ruppert T, Schlicksupp A, Hesse L, Bill E, Pipkorn R, Masters CL, Beyreuther K (1998) Copper-binding amyloid precursor protein undergoes a site-specific fragmentation in the reduction of hydrogen peroxide. Biochemistry 37:7224-7230.

Okado H, Okamoto H (1995) Developmental regulation of Xenopus beta-amyloid precursor protein gene expression. Gerontology 41:7-12.

Pitas RE, Boyles JK, Lee SH, Hui D, Weisgraber KH (1987) Lipoproteins and their receptors in the central nervous system: characterization of the lipoproteins in cerebrospinal fluid and identification of apolipoprotein B, E (LDL) receptors in the brain. J Biol Chem 262:14352-14360.

Praticò D, Uryu K, Leight S, Trojanowski JQ, Lee VM-Y (2001) Increased lipid peroxidation precedes amyloid plaque formation in an animal model of Alzheimer's amyloidosis. J Neurosci 21:4183-4187.

Rae TD, Schmidt PJ, Pufahl RA, Culotta VC, O'Halloran TV (1999) Undetectable intracellular free copper: the requirement of a copper chaperone for superoxide dismutase. Science 284:805-808.

Rossjohn J, Cappai R, Feil SC, Henry A, McKinstry WJ, Galatis D, Hesse L, Multhaup G, Beyreuther K, Masters CL, Parker MW (1999)
Crystal structure of the N-terminal, growth factor-like domain of $\mathrm{Alz}$ heimer amyloid precursor protein. Nat Struct Biol 6:327-331.

Ruiz FH, Gonzalez M, Bodini M, Opazo C, Inestrosa NC (1999) Cysteine 144 is a key residue in the copper reduction by the beta-amyloid precursor protein. J Neurochem 73:1288-1292.

Sambongi Y, Nagae T, Liu Y, Yoshimizu T, Takeda K, Wada Y, Futai M (1999) Sensing of cadmium and copper ions by externally exposed ADL, ASE, and ASH neurons elicits avoidance response in Caenorhabditis elegans. NeuroReport 10:753-757.

Sayre LM, Perry G, Harris PLR, Liu YH, Schubert KA, Smith MA (2000) In situ oxidative catalysis by neurofibrillary tangles and senile plaques in Alzheimer's disease: a central role for bound transition metals. J Neurochem 74:270-279.

Schippling S, Kontush A, Arlt S, Buhmann C, Sturenburg HJ, Mann U, Muller-Thomsen T, Beisiegel U (2000) Increased lipoprotein oxidation in Alzheimer's disease. Free Radic Biol Med 28:351-360.

Schmitt TL, Steiner E, Trieb K, Grubeck-Loebenstein B (1997) Amyloid beta-protein (25-35) increases cellular APP and inhibits the secretion of APPs in human extraneuronal cells. Exp Cell Res 234:336-340

Slunt HH, Thinakaran G, Von Koch C, Lo ACY, Tanzi RE, Sisodia SS (1994) Expression of a ubiquitous, cross-reactive homologue of the mouse $\beta$-amyloid precursor protein (APP). J Biol Chem 269:2637-2644.

Small DH, Nurcombe V, Reed G, Clarris H, Moir R, Beyreuther K, Masters CL (1994) A heparin-binding domain in the amyloid protein precursor of Alzheimer's disease is involved in the regulation of neurite outgrowth. J Neurosci 14:2117-2127.

Smith MA, Harris PLR, Sayre L M, Perry G (1997) Iron accumulation in Alzheimer disease is a source of redox-generated free radicals. Proc Natl Acad Sci USA 94:9866-9868.

Storey E, Katz M, Brickman Y, Beyreuther K, Masters CL (1999) Amyloid precursor protein of Alzheimer's disease: evidence for a stable, full-length, trans-membrane pool in primary neuronal cultures. Eur J Neurosci 11:1779-1788.

Torroja L, Luo LQ, White K (1996) APPL, The Drosophila member of the APP-family exhibits differential trafficking and processing in CNS neurons. J Neurosci 16:4638-4650.

Villard L, Tassone F, Crnogorac-Jurcevic T, Clancy K, Gardiner K (1998) Analysis of pufferfish homologues of the AT-rich human APP gene. Gene 210:17-24.

Waggoner DJ, Bartnikas TB, Gitlin JD (1999) The role of copper in neurodegenerative disease. Neurobiol Dis 6:221-230.

Wasco W, Bupp K, Magendantz M, Gusella JF, Tanzi RE, Solomon F (1992) Identification of a mouse brain cDNA that encodes a protein related to the Alzheimer disease-associated amyloid $\beta$ protein precursor. Proc Natl Acad Sci USA 89:10758-10762.

White AR, Zheng H, Galatis D, Maher F, Hesse L, Multhaup G Beyreuther K, Masters CL, Cappai R (1998) Survival of cultured neurons from APP knock-out mice against Alzheimer's amyloid A $\beta$ toxicity and oxidative stress. J Neurosci 18:6207-6217.

White AR, Multhaup G, Maher F, Bellingham S, Camakaris J, Zheng H, Bush AI, Beyreuther K, Masters CL, Cappai R (1999a) The Alzheimer's disease amyloid precursor protein modulates copper-induced toxicity and oxidative stress in primary neuronal cultures. J Neurosci 19:9170-9179.

White AR, Reyes R, Mercer JFB, Camakaris J, Zheng H, Bush AI, Multhaup G, Beyreuther K, Masters CL, Cappai R (1999b) Copper levels are increased in the cerebral cortex and liver of APP and APLP2 knockout mice. Brain Res 842:439-444.

Yamada T, Wakabayashi K, Kakihara T, Gejyo F, Takahashi H, Itoh Y (1997) Further characterization of a monoclonal antibody recognizing apolipoprotein $\mathrm{E}$ peptides in amyloid deposits. Ann Clin Lab Sci 27:276-281.

Yankner BA, Duffy LK, Kirschner DA (1990) Neurotrophic and neurotoxic effects of amyloid $\beta$ protein: reversal by tachykinin neuropeptides. Science 250:279-282.

Yim MB, Kang JH, Yim HS, Kwak HS, Chock PB, Stadtman ER (1996) A gain-of-function of an amyotrophic lateral sclerosis-associated $\mathrm{Cu}, \mathrm{Zn}$-superoxide dismutase mutant: an enhancement of free radical formation due to a decrease in $\mathrm{Km}$ for hydrogen peroxide. Proc Natl Acad Sci USA 93:5709-5714. 